\title{
Childhood intermittent and persistent rhinitis prevalence and climate and vegetation: a global ecologic analysis
}

\author{
Elaine Fuertes, MSc ${ }^{* \dagger}$; Barbara K. Butland, MSc ${ }^{\ddagger}$; H. Ross Anderson, MD ${ }^{\ddagger \S}$; Chris Carlsten, MD ${ }^{*}$; \\ David P. Strachan, MD ${ }^{\ddagger}$; Michael Brauer, PhD*ף; and the ISAAC Phase Three Study Group \\ * School of Population and Public Health, University of British Columbia, Vancouver, British Columbia, Canada \\ ${ }^{\dagger}$ Institute of Epidemiology I, Helmholtz Zentrum München - German Research Centre for Environmental Health, Neuherberg, Germany \\ ${ }^{\ddagger}$ MRC-PHE Centre for Environment and Health, St Georges, University of London, London, United Kingdom \\ ${ }^{\S}$ MRC-PHE Centre for Environment and Health, King's College London, London, United Kingdom \\ 'Department of Medicine, University of British Columbia, Vancouver, British Columbia, Canada
}

\section{A R T I C L E I N F O}

\section{Article history:}

Received for publication March 19, 2014.

Received in revised form June 17, 2014.

Accepted for publication June 25, 2014.

\begin{abstract}
A B S T R A C T
Background: The effect of climate change and its effects on vegetation growth, and consequently on rhinitis, are uncertain.

Objective: To examine between- and within-country associations of climate measures and the normalized difference vegetation index with intermittent and persistent rhinitis symptoms in a global context.

Methods: Questionnaire data from 6- to 7-year-olds and 13- to 14-year-olds were collected in phase 3 of the International Study of Asthma and Allergies in Childhood. Associations of intermittent ( $>1$ symptom report but not for 2 consecutive months) and persistent (symptoms for $\geq 2$ consecutive months) rhinitis symptom prevalences with temperature, precipitation, vapor pressure, and the normalized difference vegetation index were assessed in linear mixed-effects regression models adjusted for gross national income and population density. The mean difference in prevalence per 100 children (with 95\% confidence intervals [CIs]) per interquartile range increase of exposure is reported.

Results: The country-level intermittent symptom prevalence was associated with several country-level climatic measures, including the country-level mean monthly temperature $\left(6.09^{\circ} \mathrm{C} ; 95 \% \mathrm{CI}, 2.06\right.$ $10.11^{\circ} \mathrm{C}$ per $\left.10.4^{\circ} \mathrm{C}\right)$, precipitation $(3.10 \mathrm{~mm} ; 95 \% \mathrm{CI}, 0.46-5.73 \mathrm{~mm}$; per $67.0 \mathrm{~mm}$ ), and vapor pressure (6.21 hPa; 95\% CI, 2.17-10.24 hPa; per $10.4 \mathrm{hPa}$ ) among 13- to 14-year-olds (222 center in 94 countries). The center-level persistent symptom prevalence was positively associated with several center-level climatic measures. Associations with climate were also found for the 6- to 7-year-olds (132 center in 57 countries).

Conclusion: Several between- and within-country spatial associations between climatic factors and intermittent and persistent rhinitis symptom prevalences were observed. These results provide suggestive evidence that climate (and future changes in climate) may influence rhinitis symptom prevalence.
\end{abstract}

(c) 2014 American College of Allergy, Asthma \& Immunology. Published by Elsevier Inc. All rights reserved.

\section{Introduction}

The prevalence of allergic rhinitis is increasing in most countries. ${ }^{1}$ Environmental factors are suspected of being important contributing influences. There is now considerable evidence that climate change is measurably altering the timing, distribution,

Reprints: Elaine Fuertes, MSc, Ingolstädter Landstraße 1, Neuherberg D-85764, Germany; E-mail: efuertes@interchange.ubc.ca.

Disclosures: Ms Fuertes received support from the Canadian Institutes of Health Research (Sir Frederick Banting and Charles Best Canada Graduate Scholarship). Ms Butland received support from the Department of Health and the Natural Environment Research Council. quality, and quantity of allergenic plants and aeroallergens, ${ }^{2,3}$ the primary risk factors for allergic rhinitis. Such changes are occurring via meteorologic factors and through interactions with greenhouse gases. For example, ragweed in an urban site with higher temperature and carbon dioxide concentrations, similar to those associated with projected climate change, grew faster, flowered earlier, and produced significantly greater above-ground biomass and ragweed pollen compared with ragweed grown in a rural area. ${ }^{4}$ Allergic responses may also be heightened by air pollutants acting directly on the individual and/or through interactions with allergens. ${ }^{5}$

Previously, allergic rhinitis symptoms were classified as seasonal or perennial based on the timing of allergen exposure. 
However, this classification is not universally applicable and poorly reflects a patient's true experiences. ${ }^{6}$ An improved classification system, which categorizes rhinitis symptoms as intermittent or persistent, is applicable worldwide, better suits a patient's needs, and is now being recommended. ${ }^{7}$ Intermittent and persistent rhinitis are not synonymous with seasonal and perennial rhinitis and may be differentially associated with risk factors. ${ }^{8}$ Studies that assess how climatic factors may influence these 2 types of rhinitis and associated diseases are of interest ${ }^{9}$ and may provide indications as to the potential effects of future climate change.

One way to examine such associations is through the use of temporal data, as has been done in limited-area studies. ${ }^{10-13}$ However, this approach is not currently feasible on a global scale. Alternatively, spatial associations can be examined. The International Study of Asthma and Allergies in Childhood (ISAAC) is unique in its global scope and is well suited to assess spatial associations between disease and ecologic measures of exposure, such as climate. ISAAC Phase One reported a suggestive role for long-term climatic conditions on asthma and atopic eczema symptom prevalences in Western Europe ( 57 centers in 12 countries). ${ }^{14}$ No significant associations were found with allergic rhinitis symptom prevalence. The current study extends this work by taking advantage of the substantially larger ISAAC Phase Three data set and the newly adopted rhinitis classifications. Specifically, we aimed to assess spatial associations between the prevalence of intermittent and persistent rhinitis symptoms with climate and vegetation in a global context.

\section{Methods}

\section{Study Population}

The rationale and methods for ISAAC Phase Three have been previously published. ${ }^{15}$ The current analysis is limited to ISAAC centers that collected valid data on monthly rhinitis symptoms: 222 centers in 94 countries for 13- to 14-year-olds and 135 centers in 59 countries for 6- to 7-year-olds. A diagram summarizing data availability is provided in eFigure 1 . All collaborating centers obtained ethical approval from their local ethics committee or board. Letters describing the survey were sent to parents of all children. Parental completion of the questionnaire for the 6-to 7-year-olds implied consent. For the older age group, passive consent for the teenager to complete their own questionnaire at school was used by most centers.

\section{Health Outcomes}

Monthly data on rhinitis symptoms were collected via standardized parent-completed (for children 6-7 years of age) or child-completed (for children 13-14 years of age) ISAAC questionnaires (protocols available on the ISAAC website; http://isaac. auckland.ac.nz/). Individuals were asked to indicate if in the last 12 months they (or their child) had experienced a problem with sneezing or a runny or blocked nose when they (or their child) did not have a cold or flu. Subsequent questions asked whether this nose problem was accompanied by itchy eyes (at any time in the last 12 months) and in which of the past 12 months this nose problem occurred. Using the monthly data collected from the last of these questions, we calculated the prevalences of intermittent (at least 1 symptom report but not for 2 consecutive months) and persistent (symptoms for at least 2 consecutive months) rhinitis symptoms per center. Any apparent inconsistencies between stem and subsequent branch questions were accepted and not changed.

\section{Environmental Factors and Covariates}

Data on monthly mean daily temperature, total precipitation, and vapor pressure, averaged for 1991-2000 for $0.5^{\circ} \times 0.5^{\circ}$ grids (approximately $3,025 \mathrm{~km}^{2}$ ), were obtained from the
Intergovernmental Panel on Climate Change Data Distribution center. ${ }^{16,17}$ Normalized difference vegetation index (NDVI) data for 2005 were obtained from the Global Land Cover Facility at a resolution of $0.07^{\circ}$ on a 16-day basis and averaged per month. ${ }^{18,19}$ NDVI data range from -1 (water) to +1 (dense vegetation), with values close to 0 indicating barren areas of rock, sand, or snow. Using the monthly data on temperature, precipitation, vapor pressure, and NDVI, we calculated the mean, maximum, minimum, SD, and maximal difference (difference between the monthly maximum and minimum) of monthly measurements for each factor. Data on gross national income (GNI) per capita were obtained from the World Bank (Atlas Method 2003). ${ }^{20}$ When missing, GNI data were imputed using information from the Central Intelligence Agency World Fact Book (2003) (7 countries). ${ }^{21}$ Population density data for 2005 were obtained from the Socioeconomic Data and Applications center. ${ }^{22}$ Centers were classified into 5 climate types according to the Köppen climate classification system (snow/polar, equatorial, arid, warm temperate with dry winter, and warm temperate fully humid). ${ }^{23}$

The assignment of environmental variables to the centers has been previously described. ${ }^{24}$ Briefly, coordinates for the study population were assigned to a $0.1^{\circ} \times 0.1^{\circ}$ square and compared with the 8 surrounding $0.1^{\circ} \times 0.1^{\circ}$ squares (each square covers approximately $121 \mathrm{~km}^{2}$ ). Of these 9 squares, the one with the highest population density was considered the center grid and used for mapping. Climate data were mapped to this single coordinate. For population density and NDVI, the mean values of the center grid and 8 surrounding grids (each sized $0.07^{\circ} \times 0.07^{\circ}$, approximately $59 \mathrm{~km}^{2}$ ) were used. Because the resolution of the NDVI data $\left(0.07^{\circ} \times 0.07^{\circ}\right)$ is not the same as used during the original geocoding of the centers $\left(0.1^{\circ} \times 0.1^{\circ}\right)$, the sizes of the grids used for mapping the environmental factors differ. For climate, population density, and NDVI data, which were available at the center level, country-level means were calculated, ${ }^{25}$ which may not necessarily represent the true mean of a country. Data on GNI per capita were only available at the country level.

\section{Analytic Strategy}

Correlations between center-level variables were assessed using Spearman correlation coefficients because not all variables were normally distributed. Linear regression mixed models, which allow consideration of the hierarchical structure of the data, were used to assess associations between the prevalence of intermittent and persistent rhinitis symptoms with the mean, maximum, minimum, $\mathrm{SD}$, and maximal difference of monthly measurements of temperature, precipitation, vapor pressure, and NDVI (as implemented in the lme4 package ${ }^{26}$ in the statistical program $\mathrm{R}$, version 3.0.1). ${ }^{27}$ Fully adjusted models included the exposure of interest, GNI per capita, population density, and climate type. Furthermore, all models included country as a random intercept and fixed effects for both the center- and country-level representation of each explanatory variable, except for GNI per capita, which was available only at the country level. GNI per capita was included in the models because it was associated with the prevalence of atopic symptoms in worldwide analyses. ${ }^{28}$ Including a random intercept for country, to allow the prevalence rates in countries to deviate from the estimated overall prevalence to avoid spurious results, is important. ${ }^{14}$

In sensitivity analyses, models were further adjusted for air pollution (particulate matter with aerodynamic diameters $<2.5 \mu / \mathrm{m}$ and nitrogen dioxide; data sources and assignment to centers have been previously described $)^{24}$ and mutually adjusted for mean vegetation in the models estimating the effects of the climatic factors and mean temperature, precipitation, and vapor pressure in the models estimating the effects of vegetation.

Between-country effects are presented as the mean difference in country-level prevalence (per 100 children) associated with 
a 1-unit increase in country-level exposure, with corresponding 95\% confidence intervals (CIs). For countries with more than 1 participating center, the mean difference in center-level prevalence (per 100 children) associated with a 1-unit increase in center-level exposure were also estimated (within-country effects). All analyses were conducted using the statistical program $\mathrm{R}$, version 3.0.1. ${ }^{27}$

\section{Results}

\section{Distribution of Intermittent and Persistent Rhinitis Prevalences}

For the centers with 13- to 14-year-olds, the mean center prevalence for intermittent rhinitis was highest in equatorial regions (mean prevalence, 20.0), was lowest in centers with snow/ polar climates (mean prevalence, 8.9 ), and varied significantly by climate type (analysis of variance $P<.01$; Table 1 ). There was less variation by climate type for persistent symptoms (highest in warm temperate fully humid regions [mean prevalence, 16.1] and lowest in arid climates [mean prevalence, 11.9]; analysis of variance $P=.04)$.

Center-specific sample sizes and intermittent and persistent symptom prevalences are reported in eTables 1 and 2 for the 13- to 14-year-olds and 6- to 7-year-olds, respectively. Figures 1 and 2 depict the global distribution of intermittent and persistent symptom prevalence, respectively, for the centers with older age groups.

\section{Distribution and Correlation of Environmental Factors}

Characteristics of modeled variables for the 13- to 14-year-olds are given in Table 2. All 3 measures of mean climatic variables were positively correlated with intermittent rhinitis prevalence. The prevalence of persistent rhinitis was negatively correlated with mean temperature. GNI per capita was negatively correlated with intermittent rhinitis prevalence, mean temperature, and vapor pressure and positively correlated with persistent rhinitis prevalence and mean NDVI. Population density was negatively correlated with mean NDVI and positively correlated with mean temperature and vapor pressure. Positive correlations were observed among all climatic factors. Mean precipitation was positively correlated with mean vegetation. Correlations were similar for the centers with younger age groups, although for persistent rhinitis there was a positive association with precipitation and no evidence of an association with mean temperature. Correlations among different measures of the same climatic factor were also examined. For the centers with older age groups, mean temperature was positively correlated with minimum and maximum temperature and negatively correlated with measures of variability. Mean vapor pressure was positively correlated with the minimum, maximum, and SD and negatively correlated with the maximal difference. Mean precipitation and vegetation were positively correlated with all other measures of precipitation and vegetation, respectively.

\section{Table 1}

Intermittent and persistent rhinitis symptom prevalence by climate type for the centers with 13 - to 14 -year-olds (222 centers)

\begin{tabular}{|c|c|c|c|c|c|}
\hline \multirow[t]{2}{*}{ Climate type } & \multirow{2}{*}{$\begin{array}{l}\text { No. of } \\
\text { centers }\end{array}$} & \multicolumn{2}{|c|}{ Intermittent rhinitis } & \multicolumn{2}{|c|}{ Persistent rhinitis } \\
\hline & & Mean (SD) & Range & Mean (SD) & Range \\
\hline Snow/polar & 12 & $8.9(8.0)$ & $0.4-22.4$ & $14.0(9.3)$ & $3.4-28.3$ \\
\hline Arid & 23 & $13.3(10.3)$ & $0.1-45.4$ & $11.9(6.0)$ & $1.4-25.6$ \\
\hline Equatorial & 64 & $20.0(11.0)$ & $0.0-49.5$ & $12.9(8.5)$ & $0-33.8$ \\
\hline $\begin{array}{l}\text { Warm temperate } \\
\text { with dry winter }\end{array}$ & 21 & $9.5(4.0)$ & $3.5-18.6$ & $14.6(7.0)$ & $3.1-26.8$ \\
\hline $\begin{array}{l}\text { Warm temperate } \\
\text { fully humid }\end{array}$ & 102 & $15.4(7.8)$ & $0.0-44.9$ & $16.1(7.1)$ & $1.1-32.1$ \\
\hline
\end{tabular}

\section{Associations Between Rhinitis Symptoms and Environmental Factors}

Between-country associations (mean differences in countrylevel prevalence per 100 children associated with a 1-unit increase in country-level exposure) for the fully adjusted models for the centers with 13- to 14-year-olds are presented in Table 3. Intermittent symptom prevalence was positively associated with the mean and minimum monthly temperature and negatively associated with the maximal difference in monthly temperature. Intermittent symptom prevalence was also positively associated with the mean, maximum, SD, and maximal difference of monthly precipitation measurements and the mean, maximum, and minimum monthly vapor pressure measurements. Four of the 10 significant associations observed for the centers with older age groups were also significant for the centers with younger age groups (eTable 3). Persistent symptom prevalence was not associated with any climatic variable in the fully adjusted models. Confounderadjusted risk estimates for vegetation were elevated but nonsignificant for both outcomes.

For the 13- to 14-year-old age group, 37 countries had more than 1 participating center (165 centers in total). These centers were used to assess the mean difference in center-level prevalence per 100 children associated with a 1-unit increase in center-level exposure (Table 4). Within-country positive associations were observed between intermittent symptom prevalence and mean monthly temperature and the SD of monthly vapor pressure measurements. Further positive associations were also observed between persistent symptom prevalence and mean and maximum monthly temperature and the mean, maximum, minimum, and SD of monthly vapor pressure measurements. When the withincountry analyses were replicated in the 6- to 7-year-old age groups (98 centers in 23 countries), only the associations between persistent symptoms and mean, maximum, and minimum monthly vapor pressure were significant. A positive within-country association was also observed between the maximum monthly vegetation measurements and persistent symptom prevalence but only among the 6- to 7-year-old age groups.

When the analysis was restricted to children with intermittent or persistent rhinitis symptoms who also reported itchy-eye symptoms in the last 12 months, risk estimates remained in the same direction but were generally smaller and were not significant for 1 of the 10 between-country associations and 5 of the 8 withincountry associations observed for the 13- to 14-year-old age groups (eTable 5). Within-country associations were robust to the adjustment for air pollution (ie, particulate matter with aerodynamic diameters $<2.5 \mu / \mathrm{m}$ and nitrogen dioxide) and mutual adjustment for meteorologic and vegetation factors. Estimates for the betweencountry associations were also generally similar, although a loss of statistical significance was occasionally observed (data not shown).

\section{Discussion}

Several spatial associations between climatic factors and the prevalence of intermittent and persistent rhinitis symptoms were observed in a nonrandomly selected group of centers and countries that participated in ISAAC Phase Three. Our results suggest a general positive association of mean monthly temperature and vapor pressure (which were highly correlated, $r_{\mathrm{s}}=0.925$ ) and precipitation, with symptom prevalence. This cross-sectional global study is a first step in assessing how climate change can affect allergic rhinitis symptoms. However, the generalizability of the observed associations and the influence of other factors not accounted for in this analysis on the association between climate and rhinitis remain unknown.

To account for the hierarchical nature of the data, we examined between- and within-county effects (country- and center-level associations, respectively). Associations with intermittent rhinitis 


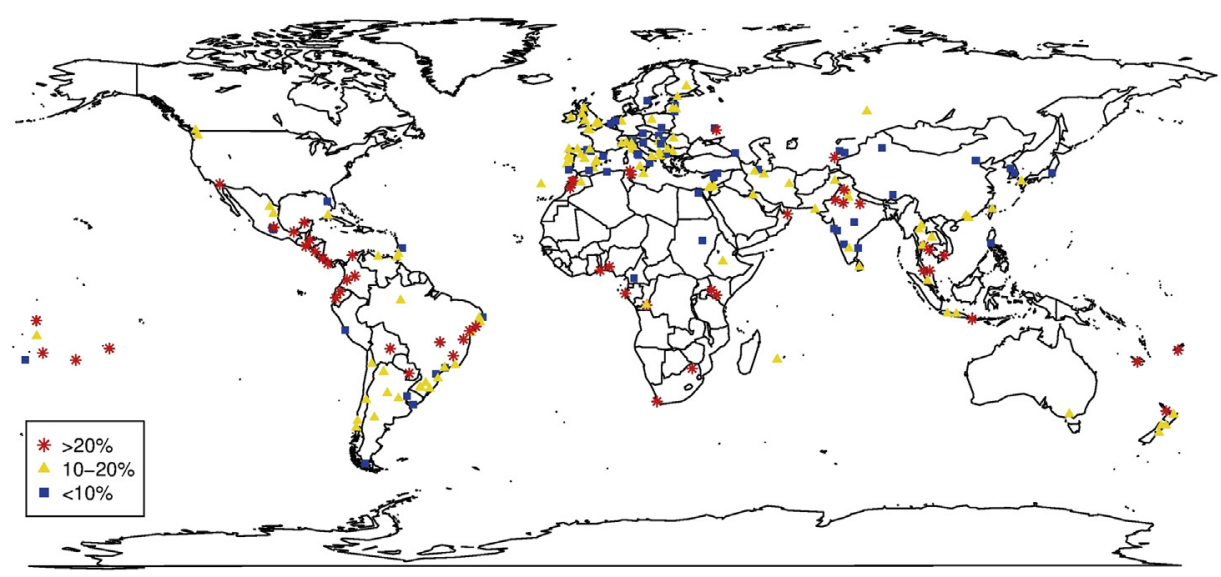

Figure 1. World map showing the center prevalence of intermittent rhinitis symptoms for the centers with 13- to 14-year-olds.

prevalence were most consistent at the country level, and only limited evidence was observed at the center level. Persistent rhinitis prevalence was only associated with climatic factors at the center level. One explanation for these findings may be that intermittent symptoms are more strongly associated with temporal changes in certain allergens affected by climate (eg, pollens and molds), whereas lifestyle factors have a greater influence on persistent symptoms. Thus, we were able to detect the relatively strong between-country associations for climate with intermittent symptom prevalence but not with persistent symptom prevalence because this latter association may be confounded by more important causal lifestyle factors that differ by country. Differences in sensitization patterns across areas are also likely to exist. Because these factors are less likely to differ within countries, the potentially weaker association for persistent symptom prevalence with climatic factors may only be detectable in the within-country analyses, which are less likely influenced by unmeasured confounding.

Our finding of a positive association of temperature, vapor pressure, and precipitation with rhinitis symptoms has been in part observed in previous single- or limited-area studies, ${ }^{10,11,13}$ but others report null findings. ${ }^{12,29-31}$ It is challenging to reconcile these previous studies with the current one because the effect of climate on allergen distribution (and thus presumably rhinitis) likely varies with local vegetation and geographical area. ${ }^{32}$ Furthermore, these studies are based on data collected from adults, whereas the current study focuses on children and teenagers. To the best of our knowledge, there are only 2 multiarea studies on rhinitis. A study of 48
European centers conducted on adults concluded that climate can account for significant variability in (mostly asthma-related) respiratory symptom prevalence, although hay fever was only associated with temperature during the hottest month. ${ }^{33}$ Another study, and the only one to include centers outside Europe and to study children, uses data from ISAAC Phase One. ${ }^{14}$ In this study, climatic factors and allergic rhinitis symptoms were not associated, although suggestive evidence for asthma and atopic eczema was reported for Western European centers. In general, worldwide associations were inconsistent. By contrast, the current study is based on a substantially larger number of centers (222 centers in 94 countries and 144 centers in 81 countries were used in the current and previous worldwide analyses for the 13- to 14-year-olds, respectively) and examines intermittent and persistent rhinitis prevalences as outcomes rather than any report of rhinitis in the last 12 months. As the prevalence of rhinitis symptoms has increased in most centers between the timing of the ISAAC Phase One (1992-1997) and ISAAC Phase Three (2000-2003) surveys, ${ }^{34}$ associations with intermittent and persistent rhinitis symptoms may be easier to detect in the ISAAC Phase Three data. The current study is also the first, to our knowledge, to examine associations between vegetation and rhinitis prevalence in a global context.

The mechanisms by which climatic factors may influence rhinitis are unclear but may be indirect via changes in indoor factors, such as dampness, which are likely to affect the distribution of indoor allergens, or via changes in pollen types, distributions, and concentrations, a phenomenon well documented in previous

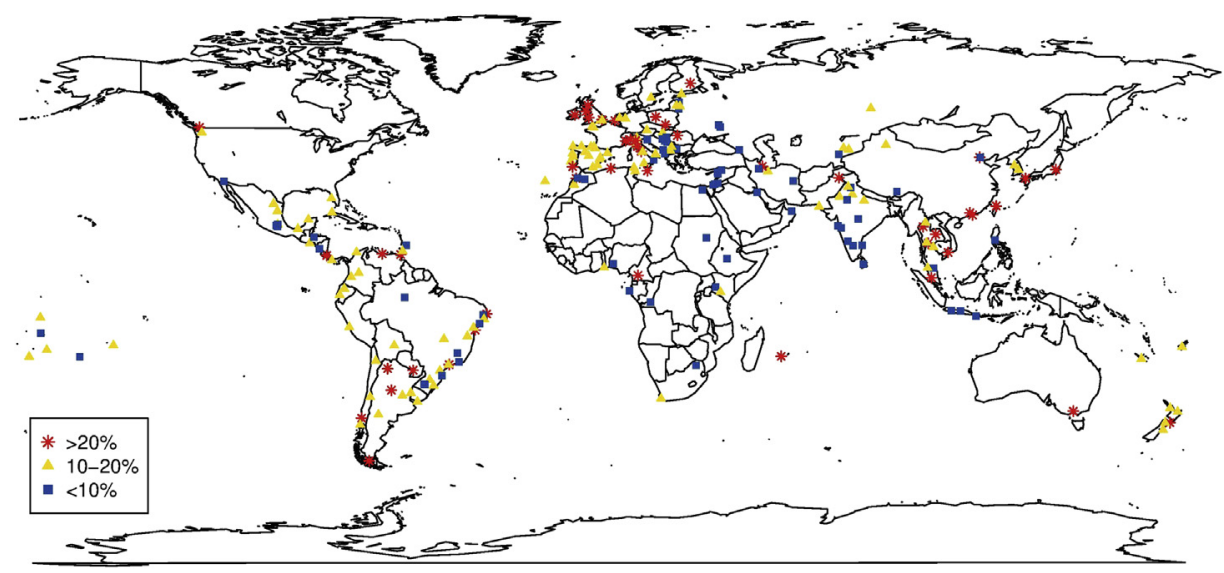

Figure 2. World map showing the center prevalence of persistent rhinitis symptoms for the centers with 13- to 14-year-olds. 
Table 2

Correlations between modeled variables for the centers with 13- to 14-year-olds (222 centers)

\begin{tabular}{|c|c|c|c|c|c|c|c|c|}
\hline \multirow[t]{2}{*}{ Variable } & \multirow[t]{2}{*}{ Period } & \multirow[t]{2}{*}{ Median (IQR) } & \multicolumn{6}{|c|}{ Spearman correlation } \\
\hline & & & $\begin{array}{l}\text { Intermittent } \\
\text { rhinitis }\end{array}$ & $\begin{array}{l}\text { Persistent } \\
\text { rhinitis }\end{array}$ & $\begin{array}{l}\text { Mean } \\
\text { NDVI }\end{array}$ & $\begin{array}{l}\text { Mean } \\
\text { temperature }\end{array}$ & $\begin{array}{l}\text { Mean } \\
\text { precipitation }\end{array}$ & $\begin{array}{l}\text { Mean vapor } \\
\text { pressure }\end{array}$ \\
\hline \multicolumn{9}{|l|}{ Health outcome } \\
\hline Intermittent rhinitis & $\sim 2000-2003$ & $14.1(9.7-20.0)$ & - & - & 0.074 & $0.361^{\mathrm{a}}$ & $0.223^{\mathrm{a}}$ & $0.332^{\mathrm{a}}$ \\
\hline Persistent rhinitis & $\sim 2000-2003$ & $13.7(8.6-19.5)$ & - & - & 0.105 & $-0.195^{\mathrm{a}}$ & 0.054 & -0.084 \\
\hline \multicolumn{9}{|l|}{ Economic/population } \\
\hline GNI per capita ${ }^{\mathrm{b}}$ & 2003 & $2950(1,483-13,070)$ & $-0.202^{\mathrm{a}}$ & $0.526^{\mathrm{a}}$ & $0.303^{\mathrm{a}}$ & $-0.441^{\mathrm{a}}$ & -0.021 & $-0.318^{\mathrm{a}}$ \\
\hline Population density & 2005 & $809(297-2,779)$ & -0.025 & 0.048 & $-0.310^{\mathrm{a}}$ & $0.222^{\mathrm{a}}$ & 0.062 & $0.183^{\mathrm{a}}$ \\
\hline \multicolumn{9}{|l|}{ Environmental factors } \\
\hline Mean NDVI, ${ }^{\mathrm{c}}$ NDVI units & 2005 & $0.4(0.3-0.5)$ & - & - & - & -0.058 & $0.422^{\mathrm{a}}$ & 0.084 \\
\hline Mean temperature, ${ }^{\circ} \mathrm{C}$ & $1991-2000$ & $17.9(12.1-24.4)$ & - & - & - & - & $0.407^{\mathrm{a}}$ & $0.925^{\mathrm{a}}$ \\
\hline Mean precipitation, mm & $1991-2000$ & $81.7(50.4-124.5)$ & - & - & - & - & - & $0.568^{\mathrm{a}}$ \\
\hline Mean vapor pressure, $\mathrm{hPa}$ & $1991-2000$ & $14.1(10.7-21.7)$ & - & - & - & - & - & - \\
\hline
\end{tabular}

Abbreviations: GNI, gross national income; IQR, interquartile range; NDVI, normalized difference vegetation index.

ap $<.05$.

${ }^{\mathrm{b}}$ Correlations with GNI per capita are with country-level variables (94 countries).

'Only 215 centers had information on NDVI.

studies covering smaller geographic areas. ${ }^{2}$ Because an NDVI estimate assigned to one geographic coordinate is unlikely to accurately reflect the vegetation of a whole area, we used the mean of 9 NDVI estimates, each assigned to a $0.07^{\circ} \times 0.07^{\circ}$ square (area coverage of approximately $59 \mathrm{~km}^{2}$ ). Most risk estimates obtained were elevated, although all but one were nonsignificant, despite moderate variation in NDVI units among countries (range of mean country vegetation estimates was 0.44 ) and within countries (eg, range of mean center vegetation estimates was 0.68 in Chile with 5 participating centers and 0.49 in Spain with 12 participating centers). Inclusion of interaction terms between vegetation and temperature exposures yielded some significant associations for intermittent rhinitis (data not shown). We also examined whether associations may be stronger among smaller countries where the NDVI estimate is more likely to reflect exposures throughout the country. Only when the analysis was restricted to countries smaller than $50,000 \mathrm{~km}^{2}$ (21 centers in 17 countries) was a positive between-country association found between intermittent symptom prevalence and the maximal difference and SD of monthly vegetation estimates. Because it is well established that pollen can disperse over large distances, ${ }^{35}$ it is possible that our ecologic study design may not be ideal for assessing associations with vegetation, which may be more heterogeneous over small areas. Furthermore, using NDVI as a surrogate for vegetation did not allow us to distinguish plant species of differing allergenicity.

An important strength of this study is the ability to examine associations between and within countries using a multilevel modeling approach. Examining between-country associations allows the use of the entire data set, thereby taking full advantage of the large number and exposure contrasts of the countries

Table 3

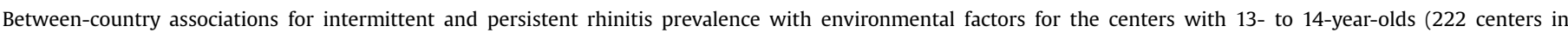
94 countries)

\begin{tabular}{|c|c|c|}
\hline \multirow[t]{2}{*}{ Country-level environmental factor } & \multicolumn{2}{|c|}{ Mean difference in country-level prevalence $(95 \% \mathrm{CI})$ per 100 children per 1 -U increase in country-level exposure } \\
\hline & Intermittent rhinitis & Persistent rhinitis \\
\hline \multicolumn{3}{|l|}{ Temperature } \\
\hline Mean $\left(10.4^{\circ} \mathrm{C}\right)$ & $0.59(0.20 \text { to } 0.98)^{\mathrm{b}}$ & $-0.02(-0.34$ to 0.29$)$ \\
\hline Maximum $\left(4.6^{\circ} \mathrm{C}\right)$ & $0.33(-0.15$ to 0.82$)$ & $-0.10(-0.47$ to 0.27$)$ \\
\hline Minimum $\left(16.1^{\circ} \mathrm{C}\right)$ & $0.43(0.15 \text { to } 0.71)^{\mathrm{b}}$ & $-0.02(-0.25$ to 0.21$)$ \\
\hline $\mathrm{SD}\left(2.1^{\circ} \mathrm{C}\right)$ & $-0.56(-1.62$ to 0.49$)$ & $0.05(-0.78$ to 0.88$)$ \\
\hline Maximal difference $\left(12.5^{\circ} \mathrm{C}\right)$ & $-0.36(-0.67 \text { to }-0.05)^{c}$ & $0.07(-0.18$ to 0.32$)$ \\
\hline \multicolumn{3}{|l|}{ Precipitation } \\
\hline Mean $(67.0 \mathrm{~mm})$ & $0.05(0.01 \text { to } 0.09)^{c}$ & $0.01(-0.02$ to 0.04$)$ \\
\hline Maximum (166.1 mm) & $0.02(0.01 \text { to } 0.04)^{c}$ & $0(-0.01$ to 0.02$)$ \\
\hline Minimum (42.7 mm) & $0(-0.07$ to 0.07$)$ & $0(-0.06$ to 0.05$)$ \\
\hline $\mathrm{SD}(51.5 \mathrm{~mm})$ & $0.09(0.03 \text { to } 0.14)^{\mathrm{b}}$ & $0.01(-0.04$ to 0.05$)$ \\
\hline Maximal difference (137.8 mm) & $0.03(0.01 \text { to } 0.05)^{\mathrm{a}}$ & $0(-0.02$ to 0.02$)$ \\
\hline \multicolumn{3}{|l|}{ Vapor pressure } \\
\hline Mean (10.4 hPa) & $0.60(0.21 \text { to } 0.99)^{\mathrm{b}}$ & $0.17(-0.15$ to 0.48$)$ \\
\hline Maximum (8.6 hPa) & $0.44(0.07 \text { to } 0.81)^{c}$ & $0.18(-0.11$ to 0.47$)$ \\
\hline Minimum (10.8 hPa) & $0.55(0.17 \text { to } 0.93)^{\mathrm{b}}$ & $0.12(-0.19$ to 0.44$)$ \\
\hline $\mathrm{SD}(2.0 \mathrm{hPa})$ & $0.25(-1.24$ to 1.74$)$ & $0.75(-0.38$ to 1.87$)$ \\
\hline Maximal difference (4.9 hPa) & $-0.23(-0.69$ to 0.23$)$ & $0.23(-0.12$ to 0.58$)$ \\
\hline \multicolumn{3}{|l|}{ Vegetation $^{\mathrm{d}}$} \\
\hline Mean $(0.1)$ & $8.03(-8.75$ to 24.81$)$ & $9.45(-3.84$ to 22.75$)$ \\
\hline Maximum (0.1) & $6.33(-8.54$ to 21.20$)$ & $7.98(-3.91$ to 19.87$)$ \\
\hline Minimum $(0.1)$ & $4.31(-13.52$ to 22.14$)$ & $8.48(-5.57$ to 22.53$)$ \\
\hline $\mathrm{SD}(0.02)$ & $11.57(-41.84$ to 64.98$)$ & $19.32(-23.92$ to 62.56$)$ \\
\hline Maximal difference $(0.1)$ & $5.48(-13.14$ to 24.11$)$ & $3.51(-11.51$ to 18.53$)$ \\
\hline
\end{tabular}

Abbreviation: CI, confidence interval.

${ }^{a}$ All models adjusted for center mean exposure of interest, center, and country mean population density, country gross national income per capita, and climate type. ${ }^{\mathrm{b}} \mathrm{P}<.01$.

${ }^{\mathrm{c}} P<.05$.

${ }^{\mathrm{d}}$ Vegetation data only available for 215 centers in 87 countries. 
Table 4

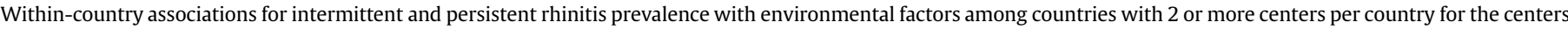
with 13 - to 14 -year-olds ( 165 centers in 37 countries) ${ }^{a}$

\begin{tabular}{|c|c|c|}
\hline \multirow[t]{2}{*}{ Center-level environmental factor } & \multicolumn{2}{|c|}{ Mean difference in center-level prevalence $(95 \% \mathrm{CI})$ per 100 children per 1 - $U$ increase in center-level exposure } \\
\hline & Intermittent rhinitis & Persistent rhinitis \\
\hline \multicolumn{3}{|l|}{ Temperature } \\
\hline Mean $\left(10.7^{\circ} \mathrm{C}\right)$ & $0.43(0.02 \text { to } 0.84)^{\mathrm{b}}$ & $0.39(0.03 \text { to } 0.76)^{b}$ \\
\hline Maximum $\left(6.8^{\circ} \mathrm{C}\right)$ & $0.32(-0.05$ to 0.68$)$ & $0.37(0.05 \text { to } 0.70)^{b}$ \\
\hline Minimum $\left(11.9^{\circ} \mathrm{C}\right)$ & $0.26(-0.10$ to 0.62$)$ & $0.16(-0.16$ to 0.49$)$ \\
\hline $\mathrm{SD}\left(2.6^{\circ} \mathrm{C}\right)$ & $0.63(-0.50$ to 1.75$)$ & $0.71(-0.30$ to 1.72$)$ \\
\hline Maximal difference $\left(12.1^{\circ} \mathrm{C}\right)$ & $0.12(-0.28$ to 0.52$)$ & $0.22(-0.13$ to 0.58$)$ \\
\hline \multicolumn{3}{|l|}{ Precipitation } \\
\hline Mean $(68.7$ mm) & $-0.03(-0.06$ to 0.01$)$ & $-0.01(-0.04$ to 0.03$)$ \\
\hline Maximum (162.9 mm) & $-0.01(-0.02$ to 0.01$)$ & $-0.01(-0.03$ to 0$)$ \\
\hline Minimum (35.1 mm) & $-0.05(-0.11$ to 0.01$)$ & $0(-0.05$ to 0.06$)$ \\
\hline $\mathrm{SD}(58.5 \mathrm{~mm})$ & $-0.01(-0.06$ to 0.04$)$ & $-0.04(-0.08$ to 0$)$ \\
\hline Maximal difference (161.5 mm) & $0(-0.02$ to 0.02$)$ & $-0.01(-0.03$ to 0$)$ \\
\hline \multicolumn{3}{|l|}{ Vapor pressure } \\
\hline Mean $(8.4 \mathrm{hPa})$ & $0.22(-0.15$ to 0.59$)$ & $0.37(0.04 \text { to } 0.70)^{\mathrm{b}}$ \\
\hline Maximum (10.1 hPa) & $0.20(-0.08$ to 0.49$)$ & $0.31(0.06 \text { to } 0.56)^{b}$ \\
\hline Minimum $(6.2 \mathrm{hPa})$ & $0.25(-0.17$ to 0.67$)$ & $0.39(0.02 \text { to } 0.76)^{b}$ \\
\hline $\mathrm{SD}(2.4 \mathrm{hPa})$ & $1.14(0.06 \text { to } 2.21)^{\mathrm{b}}$ & $1.32(0.37 \text { to } 2.27)^{c}$ \\
\hline Maximal difference (5.7 hPa) & $0.30(-0.10$ to 0.71$)$ & $0.28(-0.09$ to 0.64$)$ \\
\hline \multicolumn{3}{|l|}{ Vegetation } \\
\hline Mean (0.2) & $-1.25(-10.81$ to 8.31$)$ & $-2.89(-11.42$ to 5.64$)$ \\
\hline Maximum (0.2) & $-0.40(-8.82$ to 8.02$)$ & $-0.25(-7.79$ to 7.29$)$ \\
\hline Minimum (0.2) & $-2.93(-13.61$ to 7.76$)$ & $-5.47(-14.98$ to 4.04$)$ \\
\hline $\mathrm{SD}(0.05)$ & 0.75 ( -36.50 to 37.99$)$ & 7.53 ( -25.95 to 41.02$)$ \\
\hline Maximal difference $(0.2)$ & $3.19(-9.41$ to 15.78$)$ & $6.94(-4.31$ to 18.20$)$ \\
\hline
\end{tabular}

Abbreviation: $\mathrm{CI}$, confidence interval.

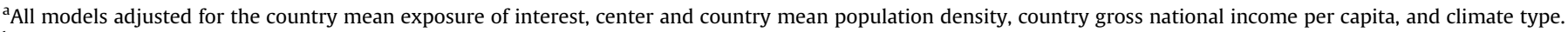
${ }^{\mathrm{b}} \mathrm{P}<.05$.

${ }^{\mathrm{c}} P<.01$.

participating in ISAAC Phase Three. However, it is likely that substantial between-country differences were not captured by model adjustments for GNI per capita, climate type, or air pollution, and thus we cannot exclude the possibility that residual confounding may be affecting the between-country associations. The differentiation between intermittent and persistent symptoms is however less likely to be affected by translation or awareness artifacts attributable to language and culture, which often hinder international comparisons of prevalence in ISAAC (and other questionnaire-based studies). Nevertheless, it remains possible that there may be some variation in the way the questionnaires were completed or administered. Confounding, although still possible, is less of a concern for the within-country associations because causal factors are less likely to differ to the same degree within countries as between countries. However, we did not account for individual risk factors, a limitation common to all ecologic studies. Given that only countries with 2 or more participating centers per country can contribute to the within-country analysis, these results are hindered by a lack of statistical power in terms of fewer centers and smaller exposure variation. Finally, a possible limitation of this study is that associations were not adjusted for multiple testing because it is not clear that the different exposure metrics (eg, the mean, maximum, minimum, SD, and maximal difference of temperature) represent the same exposure, especially not worldwide, and correcting for multiple testing can lead to conservative results when exposures are highly correlated.

ISAAC, given its size and worldwide coverage, which spans several different climate zones, is unique in its ability to assess the associations considered in this report. The collection of data from both 13- to 14-year-olds and 6- to 7-year-olds, using the standardized and validated ISAAC protocol and questionnaire, allowed for replication of analyses. The direction of estimates was the same for all significant between-country associations with intermittent symptoms and all but one within-country associations with persistent symptoms. Given that symptom data were collected for each month and therefore the period in days and weeks of each rhinitis episode was not available, our persistent rhinitis definition differs slightly from that proposed by the Allergic Rhinitis and Its Impact on Asthma workshop group, which requires symptoms to persist for more than 4 days per week and for more than 4 consecutive weeks. ${ }^{7}$ The outcome definitions used in this report also deviate from those commonly used by ISAAC for allergic rhinitis (rhinoconjunctivitis), which requires a positive report of both nose symptoms and itchy eyes. ${ }^{1}$ Information on itchy eyes was only collected for one time point covering anytime in the last 12 months. A sensitivity analysis that considered intermittent or persistent symptoms and itchy eyes anytime in the last 12 months as alternate outcomes yielded similar results, especially for the between-country associations. Associations for both intermittent and persistent symptoms were stronger for children who reported that their nose problems interfered with daily activities "a moderate amount" and a "lot" compared with those who answered "not at all" or "no answer provided," which may suggest that climate not only influences the prevalence of disease but also the severity of symptoms (data not shown). However, we were unable to replicate this finding using the more stringent severe symptom definition normally used by ISAAC (which identifies severe symptoms as those that interfere with daily activities "a lot") because the center prevalences of severe symptoms were quite low. As with all questionnaire-based data, recall bias is possible. Symptom reports were highest in the months before and after the month the surveys were administered. We do not anticipate that this would affect the results because the outcomes considered were not month specific. Caution should be applied in interpretation of these data as representative of world prevalence because the centers and countries participating in ISAAC were not randomly selected. Finally, although during the design of this analysis we attempted to use data from the same period, not all data sets overlap temporally.

In conclusion, several between- and within-country spatial associations between climatic factors (temperature, vapor pressure, 
and precipitation) and the prevalence of intermittent and persistent rhinitis symptoms were observed in this cross-sectional global analysis. These results provide suggestive evidence that climate influences the prevalence of rhinitis symptoms. Although not conclusive, our results represent a first step in investigating how future climate change may affect rhinitis symptom prevalence.

\section{Acknowledgments}

We thank all children, parents, and school teachers for their cooperation and participation. We also thank the many unnamed fieldworkers and funding agencies that supported ISAAC in their localities, as well as Mary Field-Smith for her assistance with the preparation of this article. All investigators in ISAAC Phase Three are listed in the eAppendix.

\section{References}

[1] Björkstén B, Clayton T, Ellwood P, Strachan D; ISAAC Phase Three Study Group. Worldwide time trends for symptoms of rhinitis and conjunctivitis: Phase III of the International Study of Asthma and Allergies in Childhood. Pediatr Allergy Immunol. 2008:19:110-124.

[2] Shea KM, Truckner RT, Weber RW, Peden DB. Climate change and allergic disease. J Allergy Clin Immunol. 2008;122:443-453.

[3] Beggs PJ. Impacts of climate change on aeroallergens: past and future. Clin Exp Allergy. 2004;34:1507-1513.

[4] Ziska LH, Gebhard DE, Frenz DA, Faulkner S, Singer BD, Straka JG. Cities as harbingers of climate change: common ragweed, urbanization, and public health. J Allergy Clin Immunol. 2003;111:290-295.

[5] Ghiani A, Aina R, Asero R, Bellotto E, Citterio S. Ragweed pollen collected along high-traffic roads shows a higher allergenicity than pollen sampled in vegetated areas. Allergy. 2012;67:887-894.

[6] Bousquet J, Khaltaev N, Cruz AA, et al. Allergic Rhinitis and its Impact on Asthma (ARIA). Allergy. 2008;63:8-160.

[7] Bousquet J, Cauwenberge P, Khaltaev N. Allergic Rhinitis and its Impact on Asthma. J Allergy Clin Immunol. 2001;108:S147-S334.

[8] Bousquet J, Annesi-Maesano I, Carat F, et al. Characteristics of intermittent and persistent allergic rhinitis: DREAMS study group. Clin Exp Allergy. 2005; 35:728-732.

[9] Lin GC, Zacharek MA. Climate change and its impact on allergic rhinitis and other allergic respiratory diseases. Curr Opin Otolaryngol Head Neck Surg. 2012;20:188-193.

[10] Kim S-H, Park H-S, Jang J-Y. Impact of meteorological variation on hospita visits of patients with tree pollen allergy. BMC Public Health. 2011;11:890.

[11] Ariano R, Canonica GW, Passalacqua G. Possible role of climate changes in variations in pollen seasons and allergic sensitizations during 27 years. Ann Allergy Asthma Immunol. 2010;104:215-222.

[12] Breton M-C, Garneau M, Fortier I, Guay F, Louis J. Relationship between climate, pollen concentrations of Ambrosia and medical consultations for allergic rhinitis in Montreal, 1994-2002. Sci Total Environ. 2006;370:39-50.

[13] Newhouse CP, Levetin E. Correlation of environmental factors with asthma and rhinitis symptoms in Tulsa, OK. Ann Allergy Asthma Immunol. 2004:92:356-366.

[14] Weiland SK, Hüsing A, Strachan DP, Rzehak P, Pearce N. Climate and the prevalence of symptoms of asthma, allergic rhinitis, and atopic eczema in children. Occup Environ Med. 2004;61:609-615.
[15] Ellwood P, Asher M, Beasley R, Clayton TO, Stewart AW; ISAAC Steering Committee. The International Study of Asthma and Allergies in Childhood (ISAAC): Phase Three rationale and methods. Int J Tuberc Lung Dis. 2005;9:10-16.

[16] Mitchell TD, Jones PD. An improved method of constructing a database of monthly climate observations and associated high-resolution grids. Int J Clim. 2005;25:693-712.

[17] Mitchell T. High Resolution Observational Climatologies version 2.1, University of East Anglia: Climate Research Unit 2004, http://www.ipcc-data.org/ obs/cru_ts2_1.html. Accessed April 4, 2012.

[18] Pinzon J, Brown M, Tucker C. Satellite time series correction of orbital drift artifacts using empirical mode decomposition. In: Huang N, ed. Hilbert-Huang Transform: Introduction and Applications; 2005:167-186.

[19] Tucker CJ, Pinzon JE, Brown ME, et al. An extended AVHRR 8-km NDVI dataset compatible with MODIS and SPOT vegetation NDVI data. Int J Remote Sens. 2005;26:4485-4498.

[20] World Bank. GNI per Capita, Atlas Method (current US\$). 2012. http://data. worldbank.org/indicator/NY.GNP.PCAP.CD?order=wbapi_data_value_2001+wbapi_ data value + wbapi_data_value-last\&sort=asc\&page $=2$. Accessed March 13, 2012.

[21] Central Intelligence Agency. The World Factbook 2003. Washington, DC: Central Intelligence Agency; 2007. https://www.cia.gov/library/publications/ download/download-2003/index.html. Accessed March 13, 2012.

[22] Socioeconomic Data and Applications Center (SEDAC). Gridded Population of the World (GPW), v3 1997, sedac.ciesin.columbia.edu/search/data?contains= gridded + population + of + the + world + v3. Accessed February 7, 2012.

[23] Kottek M, Grieser J, Beck C, Rudolf B, Rubel F. World Map of the KoeppenGeiger climate classification updated. Meteorol Z. 2006;15:259-263.

[24] Anderson H, Butland B, van Donkelaar A, et al. Satellite-based estimates of ambient air pollution and global variations in childhood asthma prevalence. Environ Health Perspect. 2012;120:1333-1339.

[25] Begg MD, Parides MK. Separation of individual-level and cluster-level covariate effects in regression analysis of correlated data. Stat Med. 2003;22: 2591-2602.

[26] Bates D, Maechler M, Bolker B, Walker S. Lme4: linear mixed-effects models using Eigen and S4. 2014. R package version 1.1-6. http://CRAN.R-project.org/ package $=$ lme 4 .

[27] R Core Team. R: A Language and Environment for Statistical Computing. Vienna, Austria: R Foundation for Statistical Computing; 2012. http://www.R-project. org/.

[28] Stewart AW, Mitchell EA, Pearce N, et al. The relationship of per capita gross national product to the prevalence of symptoms of asthma and other atopic diseases in children. Int J Epidemiol. 2001:303:173-179.

[29] Bhattacharyya N. Does annual temperature influence the prevalence of otolaryngologic respiratory diseases? Laryngoscope. 2009;119:1882-1886.

[30] Zanolin ME, Pattaro C, Corsico A, et al. The role of climate on the geographic variability of asthma, allergic rhinitis and respiratory symptoms: results from the Italian study of asthma in young adults. Allergy. 2004;59: 306-314.

[31] De Marco R, Poli A, Ferrari M, et al. The impact of climate and traffic-related NO2 on the prevalence of asthma and allergic rhinitis in Italy. Clin Exp Allergy. 2002;32:1405-1412.

[32] D'Amato G, Cecchi L. Effects of climate change on environmental factors in respiratory allergic diseases. Clin Exp Allergy. 2008;38:1264-1274.

[33] Verlato G, Calabrese R, De Marco R. Correlation between asthma and climate in the European Community Respiratory Health Survey. Arch Environ Health. 2002; $57: 48-52$.

[34] Asher M, Montefort S, Björkstén B, et al. Worldwide time trends in the prevalence of symptoms of asthma, allergic rhinoconjunctivitis, and eczema in childhood: ISAAC Phases One and Three repeat multicountry crosssectional surveys. Lancet. 2006;368:733-743.

[35] D'Amato G, Cecchi L, Bonini S, et al. Allergenic pollen and pollen allergy in Europe. Allergy. 2007;62:976-990. 


\section{eAppendix. International Study of Asthma and Allergies in Childhood (ISAAC) Phase One and Phase Three Study Groups}

\section{ISAAC Steering Committee}

N Aït-Khaled* (International Union Against Tuberculosis and Lung Diseases, Paris, France); HR Anderson (Division of Population Health Sciences and Education, St Georges, University of London, London, UK); MI Asher (Department of Paediatrics: Child and Youth Health, Faculty of Medical and Health Sciences, The University of Auckland, New Zealand); R Beasley* (Medical Research Institute of New Zealand, Wellington, New Zealand); B Björkstén* (Institute of Environmental Medicine, Karolinska Institutet, Stockholm, Sweden); B Brunekreef (Institute of Risk Assessment Science, Universiteit Utrecht, Netherlands); J Crane (Wellington Asthma Research Group, Wellington School of Medicine, New Zealand); P Ellwood (Department of Paediatrics: Child and Youth Health, Faculty of Medical and Health Sciences, The University of Auckland, New Zealand); C Flohr (Department of Paediatric Allergy \& Dermatology, St John's Institute of Dermatology, London, UK); S Foliaki* (Centre for Public Health Research, Massey University, Wellington, New Zealand); F Forastiere (Department of Epidemiology, Rome E Health Authority, Rome, Italy); L García-Marcos (Respiratory Medicine and Allergy Units, 'Virgen de la Arrixaca' University Children's Hospital, University of Murcia, Spain); U Keil* (Institut für Epidemiologie und Sozialmedizin, Universität Münster, Germany); CKW Lai* (Department of Medicine and Therapeutics, The Chinese University of Hong Kong SAR, China); J Mallol* (Department of Paediatric Respiratory Medicine, University of Santiago de Chile, Chile); EA Mitchell (Department of Paediatrics: Child and Youth Health, Faculty of Medical and Health Sciences, The University of Auckland, New Zealand); S Montefort* (Department of Medicine, University of Malta, Malta), J Odhiambo* (Centre Respiratory Diseases Research Unit, Kenya Medical Research Institute, Nairobi, Kenya); N Pearce (Department of Medical Statistics, Faculty of Epidemiology and Public Health, London School of Hygiene and Tropical Medicine, London, UK); CF Robertson (Murdoch Children's Research Institute, Melbourne, Australia); AW Stewart (Population Health, Faculty of Medical and Health Sciences, The University of Auckland, New Zealand); D Strachan (Division of Population Health Sciences and Education, St Georges, University of London, London, UK); E von Mutius (Dr von Haunerschen Kinderklinik de Universität München, Germany); SK Weiland $\dagger$ (Department of Epidemiology, University of Ulm, Germany); G Weinmayr (Institute of Epidemiology, University of Ulm, Germany); H Williams (Centre for Evidence Based Dermatology, Queen's Medical Centre, University Hospital, Nottingham, UK); G Wong (Department of Paediatrics, Prince of Wales Hospital, Hong Kong SAR, China).

${ }^{*}$ Regional coordinator.

$\dagger$ Deceased.

\section{ISAAC International Data Center}

MI Asher, TO Clayton, E Ellwood, P Ellwood, EA Mitchell, Department of Paediatrics: Child and Youth Health, and AW Stewart, School of Population Health, Faculty of Medical and Health Sciences, The University of Auckland, New Zealand.

\section{ISAAC Phase Three Principal Investigators}

Albania: Prof A Priftanji* (Tiranë); Algeria: Prof B Benhabylès (Wilaya of Algiers); Argentina: Dr CE Baena-Cagnani* (Córdoba), Prof Dr CD Crisci (Rosario City), Dr M Gómez (Salta), Prof GE Zabert (Neuquén); Australia: Prof CF Robertson* (Melbourne); Austria: Assoc Prof G Haidinger* (Kärnten, Urfahr-Umgebung); Barbados: Dr ME Howitt* (Barbados); Belgium: Prof J Weyler (Antwerp); Bolivia: Dr R Pinto-Vargas* (Santa Cruz); Brazil: Dr CdSD Bernhardt (Itajaí), Dr WG Borges (Brasília), Prof PAM Camargos (Belo Horizonte), Dra
MdS Cardoso (Manaus Amazonas), Prof AJLA da Cunha (Nova Iguaçu), Dr GB Fischer (Porto Alegre), Dr JM Motta (Aracaju), Prof FJ Passos (Maceió), Dr AC Pastorino (São Paulo West), Dr AC Porto Neto (Passo Fundo), Prof N Rosário (Curitiba), Assis Prof A Silva (Caruaru), Prof D Solé* (Rural Santa Maria, Santa Maria, São Paulo), Assoc Prof N Wandalsen (Santo Andre), Dr M de Britto (Recife), Assoc Prof L de Freitas Souza (Feira de Santana, Salvador, Vitória da Conquista); Bulgaria: Dr T Popov*(Sofia); Cameroon: Prof C Kuaban* (Yaounde); Canada: Prof A Ferguson (Vancouver), Prof D Rennie (Saskatoon); Channel Islands: Ms R Goulding (Jersey), Dr P Standring (Guernsey); Chile: Dr P Aguilar (South Santiago), Dr L Amarales (Punta Arenas), Dr LAV Benavides (Calama), Dr MA Calvo (Valdivia), Dra A Contreras (Chiloe); China: Prof Y-Z Chen* (Beijing, Tong Zhou), Assis Prof O Kunii (Tibet), Dr Q Li Pan (Wulumuqi), Prof N-S Zhong (Guangzhou); Colombia: Dr G Aristizábal (Bogotá), Dr AM Cepeda (Barranquilla), Dr GA Ordoñez (Cali); Congo: Prof J M'Boussa (Brazzaville); Cook Islands: Dr R Daniel* (Rarotonga); Costa Rica: Dr ME Soto-Quirós* (Costa Rica); Croatia: Dr K Lah Tomulic (Rijeka); Cuba: Dra P Varona Peréz* (La Habana); Ecuador: Dr S Barba* (Quito), Dr C Bustos (Guayaquil); Egypt: Dr ML Naguib(Cairo); El Salvador: Dr M Figueroa Colorado* (San Salvador); Estonia: Dr M-A Riikjärv* (Tallinn); Ethiopia: Assoc Prof K Melaku (Addis Ababa); Fiji: Dr R Sa'agaBanuve (Suva); Finland: Dr J Pekkanen* (Kuopio County); Former Yugoslav Republic of Macedonia (FYROM): Assoc Prof E Vlaski* (Skopje); Gabon: Dr IE Hypolite* (Port-Gentil); Georgia: Dr M Gotua* (Kutaisi); Germany: Prof Dr U Keil* (Münster); Greece: Assoc Prof J Tsanakas (Thessaloniki); Honduras: Dr A Bueso-Engelhardt* (San Pedro Sula); Hong Kong: Prof YL Lau (Hong Kong), Prof G Wong (Hong Kong); Hungary: Dr Z Novák (Szeged), Dr G Zsigmond* (Svábhegy); India: Prof S Awasthi (Lucknow), Prof J Chhatwal (Ludhiana), Prof L Kumar (Chandigarh), Dr SN Mantri (Mumbai(29)), Prof S Rego (Bangalore), Prof M Sabir (Bikaner), Dr S Salvi (Nagpur, Pimpri), Dr G Setty (Chennai (3)), Prof SK Sharma (New Delhi (7)), Prof V Singh (Jaipur), Dr PS Suresh Babu(Davangere); Indonesia: Prof Dr CB Kartasasmita (Bandung), Prof P Konthen (Bali), Dr W Suprihati (Semarang); Iran: Dr M-R Masjedi* (Birjand, Rasht, Tehran, Zanjan); Isle of Man: Dr A Steriu (Isle of Man); Italy: Dr L Armenio (Bari), Dr L Bisanti (Milano), Dr E Bonci (Cosenza), Dr E Chellini (Firenze), Dr G Ciccone (Torino), Dr V Dell'Orco (Colleferro-Tivoli), Dr F Forastiere* (Roma), Dr C Galassi (Emilia-Romagna), Dr G Giannella (Mantova), Dr S La Grutta (Palermo), Dr MG Petronio (Empoli), Dr P Sestini (Siena), Dr S Piffer (Trento); Japan: Dr H Odajima (Fukuoka), Prof M Sohei (Tochigi); Jordan: Dr F Abu-Ekteish (Amman); Kenya: Dr FO Esamai (Eldoret), Dr L Ng'ang'a* (Nairobi); Kingdom of Tonga: Dr S Foliaki (Nuku'alofa); Kuwait: Dr JA al-Momen (Kuwait); Kyrgyzstan: Dr C Imanalieva* (Balykchi, Bishkek), Prof S Sulaimanov (Jalalabat); Latvia: Dr V Svabe (Riga); Lithuania: Prof J Bojarskas (Panevezys, Siauliai), Assoc Prof J Kudzyte* (Kaunas); Malaysia: Assoc Prof J de Bruyne* (Klang Valley), Prof BS Quah (Kota Bharu), Dr KH Teh (Alor Setar); Malta: Prof S Montefort* (Malta); Mexico: Dr M Baeza-Bacab* (Mérida), Dra M Barragán-Meijueiro (Ciudad de México (3)), Dra BE Del-Río-Navarro (Ciudad de México (1)), Dr R García-Almaráz (Ciudad Victoria), Dr SN González-Díaz (Monterrey), Dr FJ LinaresZapién (Toluca), Dr JV Merida-Palacio (Mexicali Valley), Dra N Ramírez-Chanona (Ciudad de México (4)), Dr S Romero-Tapia (Villahermosa), Prof I Romieu (Cuernavaca); Morocco: Prof Z Bouayad* (Benslimane, Boulmene, Casablanca, Marrakech); Netherlands: Prof R Engels (Netherlands); New Zealand: Prof MI Asher*(Auckland), Dr C Moyes (Bay of Plenty), Dr R MacKay (Nelson), Assoc Prof P Pattemore (Christchurch), Prof N Pearce (Wellington); Nicaragua: Dr JF Sánchez* (Managua); Nigeria: Prof BO Onadeko (Ibadan); Niue: Ms M Magatogia (Niue Island); Nouvelle Caledonie: Dr I Annesi-Maesano (Nouvelle Caledonie); Pakistan: Dr N Mahmood* (Karachi), Dr MO Yusuf(Islamabad); Palestine: Dr N El Sharif* (Ramallah), Mr S Mortaja (North Gaza); Panama: Dr G Cukier* (David-Panamá); Paraguay: Dr JA Guggiari-Chase* (Asunción); Peru: 
Dr P Chiarella* (Lima); Philippines: Prof F Cua-Lim*(Metro Manila); Poland: Assoc Prof A Brêborowicz (Poznan), Assoc Prof G Lis* (Kraków); Polynesie Francaise: Dr I Annesi-Maesano (Polynesie Francaise); Portugal: Dr ML Chiera (Coimbra), Dra R Câmara (Funchal), Dr JM Lopes dos Santos (Porto), Dr C Nunes (Portimao), Dr J Rosado Pinto* (Lisbon); Republic of Ireland: Prof L Clancy (Republic of Ireland); Republique Democratique du Congo: Prof Dr J-M Kayembe (Kinshasa); Reunion Island: Dr I Annesi-Maesano (Reunion Island); Romania: Prof D Deleanu* (Cluj); Russia: Prof Dr EG Kondiourina (Novosibirsk); Samoa: Ms P Fuimaono V Pisi (Apia); Serbia and Montenegro: Dr O Adzovic (Podgorica), Dr M Hadnadjev (Novi Sad), Dr E Panic (Sombor), Dr S Zivanovic (Nis), Dr Z Zivkovic* (Belgrade); South Africa: Prof K Voyi (Polokwane), Prof HJ Zar* (Cape Town); South Korea: Prof H-B Lee* (Provincial Korea, Seoul); Spain: Dr A Arnedo-Pena (Castellón), Dr J Batlles-Garrido (Almeria), Prof A Blanco-Quirós (Valladolid), Dr RM Busquets (Barcelona), Dr I Carvajal-Urueña (Asturias), Dr G García-Hernández (Madrid), Prof L García-Marcos* (Cartagena), Dr C González Díaz (Bilbao), Prof F Guillén-Grima (Pamplona), Dr A López-Silvarrey Varela (A Coruña), Prof MM Morales Suárez-Varela (Valencia), Prof EG Pérez-Yarza (San Sebastián); Sri Lanka: Dr KD Gunasekera*(Sri Lanka); Sudan: Prof OAA Musa (Khartoum); Sultanate of Oman: Prof O Al-Rawas* (Al-Khod); Sweden: Dr H Vogt (Linköping); Syrian Arab Republic: Dr S Mohammad* (Tartous), Prof Y Mohammad (Lattakia), Dr K Tabbah (Aleppo); Taiwan: Dr J-L Huang* (Taipei), Dr C-C( Kao (Taoyuan); Thailand: $\operatorname{Dr}$ A
Kongpanichkul (Nakorn Pathom), Dr R Nettagul (Chiangrai), Dr T Prasarnphanich (Chantaburi), Assoc Prof J Teeratakulpisarn (Khon Kaen), Assoc Prof M Trakultivakorn (Chiang Mai), Dr P Vichyanond* (Bangkok); Togo: Prof O Tidjani (Lome); Tokelau: Dr T Iosefa* (Tokelau); Trinidad and Tobago: Dr MA Monteil (St Augustine, Tobago); Tunisia: Prof M Jerray (Sousse), Prof F Khaldi (Grand Tunis); USA: Prof GJ Redding (Seattle), Dr HH Windom (Sarasota); Ukraine: Assoc Prof V Ognev* (Kharkiv, Rural Kharkiv); United Kingdom: Prof HR Anderson* (North Thames, South Thames), Dr JB Austin (Scotland), Dr M Burr (Wales), Prof D Strachan (Surry-Sussex); Uruguay: Dra D Holgado* (Montevideo), Dra MC Lapides (Paysandú); Venezuela: Dr O Aldrey* (Caracas); Vietnam: Dr B Vaên Cam (Ho Chi Minh City).

*National coordinator.

\section{ISAAC National Coordinators not identified above}

Canada: M Sears; Channel Islands: HR Anderson; Chile: V Aguirre; Colombia: J Mallol (interim); Croatia: V Ahel; Fiji: L Waqatakirewa; India: J Shah; Isle of Man: HR Anderson; Kingdom of Tonga: T Fakakovi; Malaysia: J de Bruyne; Netherlands: R Otten; Nouvelle Caledonie: S Barny; Polynesie Francaise: R Chansin; Republic of Ireland: P Manning; Republique Democratique du Congo: E Bahati; Reunion Island: C Catteau; Russia: RM Khaitov; Samoa: N Tuuau-Potai; Sudan: A El Sony; Sweden: L Nilsson.

ISAAC Phase 3

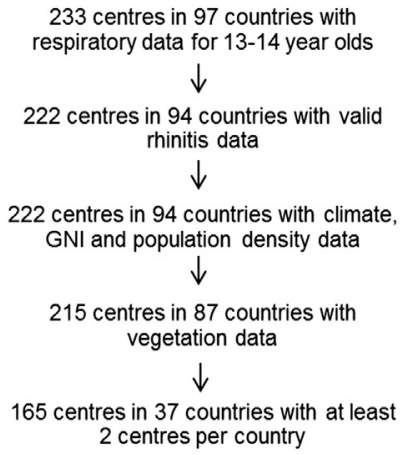

233 centres in 97 countries with respiratory data for 13-14 year olds $\downarrow$

222 centres in 94 countries with valid rhinitis data

$$
\downarrow
$$

222 centres in 94 countries with climate, $\mathrm{GNI}$ and population density data $\downarrow$

215 centres in 87 countries with vegetation data $\downarrow$

165 centres in 37 countries with at least 2 centres per country

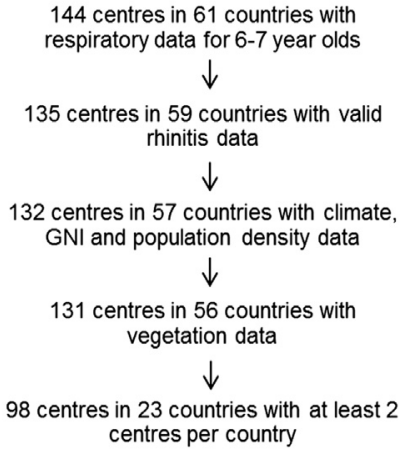

eFigure 1. Data availability for the study population. 
eTable 1

Descriptive statistics for the centers with 13- to 14-year-olds

\begin{tabular}{|c|c|c|c|c|}
\hline Country & Center & No. of children & Intermittent rhinitis prevalence & Persistent rhinitis prevalence \\
\hline \multicolumn{5}{|l|}{ Africa } \\
\hline Algeria & West Algiers & 4,203 & 0.07 & 27.96 \\
\hline Cameroon & Yaounde & 2,983 & 0.07 & 25.54 \\
\hline Congo & Brazzaville & 1,012 & 49.51 & 6.42 \\
\hline Ethiopia & Addis Ababa & 3,195 & 19.69 & 5.67 \\
\hline Gabon & Port-Gentil & 3,166 & 36.13 & 0 \\
\hline \multirow[t]{2}{*}{ Kenya } & Eldoret & 3,289 & 27.79 & 5.66 \\
\hline & Nairobi & 3,023 & 21.63 & 12.44 \\
\hline \multirow[t]{4}{*}{ Morocco } & Casablanca & 1,777 & 21.72 & 28.59 \\
\hline & Marrakech & 1,689 & 20.07 & 11.84 \\
\hline & Benslimane & 1,254 & 14.51 & 7.89 \\
\hline & Boulmene & 1,008 & 32.04 & 5.85 \\
\hline Nigeria & Ibadan & 3,142 & 35.65 & 0 \\
\hline République Democratique du Congo & Kinshasa & 2,930 & 14.71 & 3.72 \\
\hline Reunion Island & Reunion Island & 2,362 & 19.26 & 20.58 \\
\hline \multirow[t]{2}{*}{ South Africa } & Cape Town & 5,037 & 25.99 & 18.60 \\
\hline & Polokwane & 4,660 & 39.94 & 8.71 \\
\hline Sudan & Khartoum & 2,896 & 8.91 & 4.39 \\
\hline Togo & Lome & 3,090 & 21.17 & 11.62 \\
\hline \multirow[t]{2}{*}{ Tunisia } & Grand Tunis & 6,119 & 40.42 & 18.35 \\
\hline & Sousse & 3,042 & 45.40 & 18.28 \\
\hline \multicolumn{5}{|l|}{ Asia-Pacific } \\
\hline \multirow[t]{5}{*}{ China } & Beijing & 3,530 & 0.48 & 28.33 \\
\hline & Guangzhou & 3,514 & 14.34 & 29.00 \\
\hline & Tibet & 2,878 & 0.87 & 3.41 \\
\hline & Tong Zhou & 3,542 & 4.15 & 6.72 \\
\hline & Wulumuqi & 3,884 & 8.32 & 18.95 \\
\hline Hong Kong & Hong Kong & 3,321 & 13.91 & 26.80 \\
\hline \multirow[t]{3}{*}{ Indonesia } & Bali & 2,569 & 26.00 & 5.10 \\
\hline & Bandung & 2,826 & 11.92 & 5.87 \\
\hline & Semarang & 2,435 & 10.27 & 4.31 \\
\hline Japan & Fukuoka & 2,520 & 15.40 & 27.98 \\
\hline & Tochigi & 4,466 & 3.56 & 26.76 \\
\hline Malaysia & Alor Setar & 2,941 & 24.18 & 17.68 \\
\hline & Klang Valley & 3,025 & 15.27 & 21.79 \\
\hline & Kota Bharu & 2,989 & 27.57 & 6.96 \\
\hline Philippines & Metro Manila & 3,658 & 6.83 & 3.66 \\
\hline South Korea & Provincial Korea & 7,375 & 9.26 & 19.43 \\
\hline & Seoul & 2,888 & 9.38 & 17.73 \\
\hline Taiwan & Taipei & 6,378 & 8.97 & 32.08 \\
\hline & Taoyuan & 3,190 & 14.83 & 27.18 \\
\hline Thailand & Bangkok & 4,669 & 24.54 & 33.78 \\
\hline & Chantaburi & 2,901 & 28.82 & 18.58 \\
\hline & Chiang Mai & 3,538 & 15.72 & 31.85 \\
\hline & Chiangrai & 1,809 & 12.38 & 15.15 \\
\hline & Khon Kaen & 3,410 & 17.30 & 22.84 \\
\hline & Nakorn Pathom & 6,975 & 16.72 & 12.40 \\
\hline Vietnam & Ho Chi Minh City & 4,240 & 39.15 & 25.54 \\
\hline Eastern Mediterranean & & & & \\
\hline Egypt & Cairo & 3,047 & 3.48 & 1.35 \\
\hline Iran & Birjand & 2,829 & 12.12 & 8.62 \\
\hline & Rasht & 3,004 & 0.37 & 25.60 \\
\hline & Tehran & 3,119 & 10.52 & 12.95 \\
\hline & Zanjan & 2,805 & 14.15 & 6.95 \\
\hline Jordan & Amman & 2,447 & 15.53 & 4.54 \\
\hline Kuwait & Kuwait & 2,882 & 19.99 & 6.14 \\
\hline Malta & Malta & 4,136 & 16.20 & 26.04 \\
\hline Pakistan & Islamabad & 4,069 & 13.03 & 21.82 \\
\hline & Karachi & 2,999 & 11.64 & 10.87 \\
\hline Palestine & North Gaza & 3,627 & 14.09 & 1.08 \\
\hline & Ramallah & 3,929 & 10.79 & 1.99 \\
\hline Sultanate of Oman & Al-Khod & 3,747 & 20.12 & 5.47 \\
\hline Syrian Arab Republic & Aleppo & 3,063 & 4.70 & 6.33 \\
\hline & Lattakia & 3,010 & 5.22 & 3.92 \\
\hline & Tartous & 2,995 & 1.64 & 1.50 \\
\hline Indian subcontinent & & & & \\
\hline India & Bangalore & 3,440 & 16.57 & 8.95 \\
\hline & Bikaner & 3,059 & 22.20 & 19.75 \\
\hline & Chandigarh & 3,122 & 14.64 & 6.47 \\
\hline & Davangere & 2,945 & 0.58 & 9.95 \\
\hline & Jaipur & 3,607 & 29.55 & 8.34 \\
\hline & Lucknow & 3,000 & 28.77 & 11.80 \\
\hline & Ludhiana & 3,108 & 24.00 & 18.89 \\
\hline & Chennai & 2,181 & 7.79 & 1.65 \\
\hline & Mumbai & 1,829 & 4.70 & 3.34 \\
\hline & Nagpur & 4,150 & 5.20 & 4.46 \\
\hline
\end{tabular}


eTable 1 (continued)

\begin{tabular}{|c|c|c|c|c|}
\hline Country & Center & No. of children & Intermittent rhinitis prevalence & Persistent rhinitis prevalence \\
\hline & New Delhi & 3,469 & 12.19 & 13.69 \\
\hline & Pimpri & 3,128 & 1.79 & 0.74 \\
\hline Sri Lanka & Sri Lanka & 3,717 & 17.73 & 6.91 \\
\hline \multicolumn{5}{|l|}{ Latin America } \\
\hline \multirow[t]{4}{*}{ Argentina } & Córdoba & 3,445 & 14.72 & 23.08 \\
\hline & Neuquén & 3,172 & 18.13 & 19.83 \\
\hline & Rosario City & 3,099 & 11.52 & 11.55 \\
\hline & Salta & 3,000 & 15.90 & 21.73 \\
\hline Bolivia & Santa Cruz & 3,257 & 31.29 & 11.30 \\
\hline \multirow[t]{20}{*}{ Brazil } & Aracaju & 3,043 & 24.71 & 9.53 \\
\hline & Belo Horizonte & 3,088 & 20.95 & 7.71 \\
\hline & Brasília & 3,009 & 23.63 & 11.43 \\
\hline & Caruaru & 3,026 & 18.21 & 9.25 \\
\hline & Curitiba & 3,628 & 8.68 & 14.72 \\
\hline & Feira de Santana & 1,732 & 28.29 & 13.28 \\
\hline & Itajaí & 2,737 & 15.93 & 8.62 \\
\hline & Maceió & 2,745 & 12.68 & 12.09 \\
\hline & Manaus Amazonas & 3,009 & 15.29 & 6.68 \\
\hline & Nova Iguaçu & 3,185 & 11.65 & 4.27 \\
\hline & Passo Fundo & 2,949 & 18.51 & 12.55 \\
\hline & Porto Alegre & 3,007 & 18.52 & 14.57 \\
\hline & Recife & 2,865 & 0.28 & 31.13 \\
\hline & Rural Santa Maria & 3,057 & 18.29 & 6.48 \\
\hline & Salvador & 3,020 & 19.50 & 27.28 \\
\hline & Santa Maria & 3,065 & 17.32 & 8.42 \\
\hline & Santo Andre & 3,232 & 0.03 & 25.77 \\
\hline & São Paulo & 3,161 & 13.67 & 11.80 \\
\hline & São Paulo West & 3,181 & 17.73 & 14.05 \\
\hline & Vitória da Conquista & 1,679 & 30.49 & 19.54 \\
\hline \multirow[t]{5}{*}{ Chile } & Calama & 1,618 & 18.73 & 17.06 \\
\hline & Chiloe & 3,000 & 18.40 & 16.40 \\
\hline & Punta Arenas & 3,044 & 0.43 & 26.87 \\
\hline & South Santiago & 3,026 & 18.31 & 18.54 \\
\hline & Valdivia & 3,105 & 16.55 & 25.44 \\
\hline \multirow[t]{3}{*}{ Colombia } & Barranquilla & 3,204 & 36.11 & 15.79 \\
\hline & Bogotá & 3,830 & 23.94 & 15.56 \\
\hline & Cali & 3,100 & 30.45 & 14.06 \\
\hline Costa Rica & Costa Rica & 2,436 & 28.94 & 29.72 \\
\hline Cuba & La Habana & 3,026 & 16.23 & 17.32 \\
\hline \multirow[t]{2}{*}{ Ecuador } & Guayaquil & 3,082 & 20.12 & 13.95 \\
\hline & Quito & 3,014 & 23.56 & 12.14 \\
\hline El Salvador & San Salvador & 3,260 & 40.95 & 10.34 \\
\hline Honduras & San Pedro Sula & 2,675 & 33.16 & 7.07 \\
\hline \multirow[t]{10}{*}{ Mexico } & Ciudad de México (1) & 3,891 & 26.21 & 13.03 \\
\hline & Ciudad de México (3) & 3,474 & 26.11 & 4.35 \\
\hline & Ciudad de México (4) & 2,662 & 29.56 & 7.89 \\
\hline & Ciudad Victoria & 3,122 & 19.25 & 13.45 \\
\hline & Cuernavaca & 1,431 & 8.67 & 7.69 \\
\hline & Mérida & 3,019 & 25.44 & 10.40 \\
\hline & Mexicali Valley & 2,988 & 30.86 & 9.40 \\
\hline & Monterrey & 3,006 & 18.76 & 10.91 \\
\hline & Toluca & 3,021 & 5.96 & 3.08 \\
\hline & Villahermosa & 3,109 & 25.96 & 13.70 \\
\hline Nicaragua & Managua & 3,263 & 33.56 & 9.99 \\
\hline Panama & David-Panamá & 3,183 & 21.05 & 14.58 \\
\hline Paraguay & Asunción & 3,000 & 44.90 & 30.87 \\
\hline Peru & Lima & 3,022 & 0.10 & 17.97 \\
\hline \multirow{2}{*}{ Uruguay } & Montevideo & 3,177 & 7.15 & 16.18 \\
\hline & Paysandú & 1,738 & 7.71 & 10.87 \\
\hline Venezuela & Caracas & 3,000 & 14.07 & 25.30 \\
\hline North America & & & & \\
\hline Barbados & Barbados & 2,498 & 9.53 & 7.69 \\
\hline Canada & Vancouver & 2,853 & 14.72 & 22.99 \\
\hline Trinidad and Tobago & St Augustine & 3,512 & 11.10 & 22.61 \\
\hline & Tobago & 1,464 & 11.89 & 19.54 \\
\hline USA & Sarasota & 1,245 & 9.96 & 18.15 \\
\hline & Seattle & 2,422 & 15.32 & 17.22 \\
\hline Northern and Eastern Europe & & & & \\
\hline Albania & Tiranë & 2,983 & 12.67 & 3.96 \\
\hline Bulgaria & Sofia & 1,926 & 12.51 & 8.88 \\
\hline Croatia & Rijeka & 2,194 & 8.34 & 8.43 \\
\hline Estonia & Tallinn & 3,603 & 12.13 & 12.96 \\
\hline Finland & Kuopio County & 3,051 & 13.01 & 27.56 \\
\hline Former Yugoslav Republic of Macedonia & Skopje & 3,026 & 8.66 & 14.71 \\
\hline Georgia & Kutaisi & 2,650 & 7.17 & 6.94 \\
\hline Hungary & Svábhegy & 4,219 & 3.48 & 12.97 \\
\hline & Szeged & 2,889 & 3.98 & 9.69 \\
\hline
\end{tabular}


eTable 1 (continued)

\begin{tabular}{|c|c|c|c|c|}
\hline Country & Center & No. of children & Intermittent rhinitis prevalence & Persistent rhinitis prevalence \\
\hline \multirow[t]{3}{*}{ Kyrgyzstan } & Balykchi & 1,382 & 2.10 & 13.39 \\
\hline & Bishkek & 5,048 & 3.68 & 11.51 \\
\hline & Jalalabat & 2,404 & 22.42 & 6.03 \\
\hline Latvia & Riga & 1,283 & 8.81 & 9.74 \\
\hline \multirow[t]{3}{*}{ Lithuania } & Kaunas & 2,723 & 8.01 & 9.33 \\
\hline & Panevezys & 1,187 & 14.15 & 19.63 \\
\hline & Siauliai & 3,516 & 12.71 & 12.37 \\
\hline \multirow[t]{2}{*}{ Poland } & Krakow & 2,545 & 9.59 & 25.85 \\
\hline & Poznan & 1,875 & 10.72 & 25.97 \\
\hline Romania & Cluj & 3,019 & 15.07 & 21.00 \\
\hline Russia & Novosibirsk & 3,769 & 16.95 & 15.47 \\
\hline \multirow[t]{5}{*}{ Serbia and Montenegro } & Belgrade & 3,228 & 11.59 & 9.32 \\
\hline & $\mathrm{Nis}$ & 1,207 & 18.64 & 13.67 \\
\hline & Novi Sad & 1,171 & 7.94 & 6.58 \\
\hline & Podgorica & 1,014 & 10.85 & 7.89 \\
\hline & Sombor & 1,105 & 11.76 & 3.08 \\
\hline Sweden & Linköping & 2,679 & 3.84 & 15.45 \\
\hline \multirow[t]{2}{*}{ Ukraine } & Kharkiv & 2,428 & 2.59 & 6.26 \\
\hline & Rural Kharkiv & 3,968 & 20.29 & 4.36 \\
\hline \multicolumn{5}{|l|}{ Oceania } \\
\hline Australia & Melbourne & 2,192 & 16.42 & 20.39 \\
\hline Cook Islands & Rarotonga & 445 & 24.27 & 2.47 \\
\hline Fiji & Suva & 3,093 & 31.52 & 10.67 \\
\hline Kingdom of Tonga & Nuku'alofa & 2,671 & 0.04 & 17.48 \\
\hline \multirow[t]{5}{*}{ New Zealand } & Auckland & 2,870 & 20.63 & 19.79 \\
\hline & Bay of Plenty & 1,976 & 13.56 & 17.26 \\
\hline & Christchurch & 3,116 & 11.07 & 17.36 \\
\hline & Nelson & 2,305 & 10.07 & 19.70 \\
\hline & Wellington & 3,050 & 16.95 & 28.72 \\
\hline Niue & Niue Island & 79 & 22.78 & 18.99 \\
\hline Nouvelle Caledonie & Nouvelle Caledonie & 7,247 & 24.49 & 11.77 \\
\hline Polynesie Francaise & Polynesie Francaise & 4,289 & 20.73 & 10.89 \\
\hline Samoa & Apia & 2,986 & 11.82 & 2.18 \\
\hline Tokelau & Tokelau & 66 & 34.85 & 13.64 \\
\hline Western Europe & & & & \\
\hline Austria & Urfahr-Umgebung & 1,439 & 7.44 & 11.88 \\
\hline Belgium & Antwerp & 3,250 & 9.72 & 25.69 \\
\hline Channel Islands & Guernsey & 1,248 & 12.74 & 18.91 \\
\hline & Jersey & 773 & 11.64 & 16.30 \\
\hline Germany & Münster & 4,132 & 10.91 & 19.46 \\
\hline Isle of Man & Isle of Man & 1,716 & 16.84 & 21.45 \\
\hline Italy & Bari & 1,287 & 18.34 & 18.57 \\
\hline & Colleferro-Tivoli & 1,361 & 9.63 & 10.14 \\
\hline & Cosenza & 925 & 6.49 & 8.76 \\
\hline & Emilia-Romagna & 1,347 & 13.29 & 19.90 \\
\hline & Empoli & 1,229 & 15.79 & 15.30 \\
\hline & Firenze & 1,383 & 12.65 & 18.51 \\
\hline & Mantova & 1,114 & 11.13 & 23.07 \\
\hline & Milano & 1,410 & 10.85 & 22.34 \\
\hline & Palermo & 1,221 & 11.96 & 18.18 \\
\hline & Roma & 1,325 & 8.83 & 26.94 \\
\hline & Siena & 1,082 & 11.74 & 24.77 \\
\hline & Torino & 1,180 & 12.37 & 21.36 \\
\hline & Trento & 1,311 & 4.35 & 11.82 \\
\hline The Netherlands & The Netherlands & 6,896 & 8.45 & 18.16 \\
\hline Portugal & Coimbra & 1,177 & 10.79 & 11.21 \\
\hline & Funchal & 3,161 & 10.16 & 10.09 \\
\hline & Lisbon & 3,024 & 12.10 & 15.31 \\
\hline & Portimao & 1,109 & 0.09 & 20.02 \\
\hline & Porto & 3,336 & 14.81 & 15.08 \\
\hline Republic of Ireland & Republic of Ireland & 3,089 & 13.05 & 20.78 \\
\hline Spain & A Coruña & 2,979 & 14.84 & 19.54 \\
\hline & Almeria & 4,051 & 8.49 & 14.76 \\
\hline & Asturias & 4,184 & 16.32 & 18.57 \\
\hline & Barcelona & 3,066 & 9.65 & 12.26 \\
\hline & Bilbao & 3,401 & 8.17 & 14.61 \\
\hline & Cartagena & 3,998 & 14.76 & 15.68 \\
\hline & Castellón & 4,024 & 11.16 & 19.38 \\
\hline & Madrid & 2,652 & 12.14 & 14.86 \\
\hline & Pamplona & 2,932 & 9.89 & 13.27 \\
\hline & San Sebastián & 1,195 & 10.88 & 13.39 \\
\hline & Valencia & 3,132 & 12.77 & 11.11 \\
\hline & Valladolid & 2,944 & 15.18 & 15.29 \\
\hline United Kingdom & North Thames & 2,356 & 16.38 & 20.12 \\
\hline & Scotland & 4,662 & 12.91 & 22.31 \\
\hline & South Thames & 2,432 & 15.79 & 17.56 \\
\hline & Surrey-Sussex & 5,082 & 12.99 & 18.91 \\
\hline & Wales & 2,501 & 13.39 & 21.63 \\
\hline
\end{tabular}


eTable 2

Descriptive statistics for the centers with 6- to 7-year-olds

\begin{tabular}{|c|c|c|c|c|}
\hline Country & Center & No. of children & Intermittent rhinitis prevalence & Persistent rhinitis prevalence \\
\hline \multicolumn{5}{|l|}{ Africa } \\
\hline Nigeria & Ibadan & 2,396 & 16.65 & 0 \\
\hline South Africa & Polokwane & 3,480 & 26.15 & 4.57 \\
\hline \multicolumn{5}{|l|}{ Asia-Pacific } \\
\hline Hong Kong & Hong Kong & 4,448 & 13.02 & 23.40 \\
\hline Indonesia & Bandung & 2,503 & 12.74 & 2.36 \\
\hline Japan & Fukuoka & 2,958 & 7.98 & 18.09 \\
\hline \multirow[t]{3}{*}{ Malaysia } & Alor Setar & 3,786 & 10.17 & 3.86 \\
\hline & Klang Valley & 3,044 & 9.59 & 4.86 \\
\hline & Kota Bharu & 3,110 & 11.32 & 3.83 \\
\hline \multirow[t]{2}{*}{ South Korea } & Provincial Korea & 4,258 & 6.95 & 16.67 \\
\hline & Seoul & 1,760 & 7.05 & 18.58 \\
\hline \multirow[t]{2}{*}{ Taiwan } & Taipei & 4,832 & 6.21 & 31.42 \\
\hline & Taoyuan & 3,293 & 8.78 & 30.31 \\
\hline \multirow[t]{6}{*}{ Thailand } & Bangkok & 4,209 & 19.51 & 22.62 \\
\hline & Chantaburi & 3,321 & 18.85 & 14.39 \\
\hline & Chiang Mai & 3,106 & 15.04 & 13.17 \\
\hline & Chiangrai & 1,677 & 10.73 & 12.10 \\
\hline & Khon Kaen & 2,658 & 11.96 & 18.81 \\
\hline & Nakorn Pathom & 1,821 & 12.85 & 12.03 \\
\hline Vietnam & Ho Chi Minh City & 3,879 & 19.49 & 15.49 \\
\hline \multicolumn{5}{|l|}{ Eastern Mediterranean } \\
\hline \multirow[t]{4}{*}{ Iran } & Birjand & 2,693 & 7.98 & 4.68 \\
\hline & Rasht & 3,057 & 0.10 & 30.75 \\
\hline & Tehran & 3,008 & 3.36 & 4.89 \\
\hline & Zanjan & 2,777 & 17.21 & 8.64 \\
\hline Jordan & Amman & 2,598 & 11.97 & 4.35 \\
\hline Malta & Malta & 3,795 & 9.01 & 16.02 \\
\hline \multirow[t]{2}{*}{ Pakistan } & Islamabad & 3,966 & 5.77 & 12.36 \\
\hline & Karachi & 2,113 & 6.39 & 5.92 \\
\hline Palestine & North Gaza & 3,575 & 11.78 & 2.66 \\
\hline & Ramallah & 3,754 & 8.98 & 2.66 \\
\hline Sultanate of Oman & Al-Khod & 4,130 & 10.94 & 3.95 \\
\hline Syrian Arab Republic & Lattakia & 2,373 & 3.75 & 5.44 \\
\hline & Tartous & 2,734 & 7.68 & 10.02 \\
\hline Indian subcontinent & & & & \\
\hline India & Davangere & 3,043 & 0.82 & 7.59 \\
\hline & Jaipur & 2,545 & 17.25 & 9.12 \\
\hline & Lucknow & 3,000 & 15.07 & 7.57 \\
\hline & Ludhiana & 3,225 & 9.64 & 7.26 \\
\hline & Mumbai & 1,833 & 3.66 & 3.76 \\
\hline & Nagpur & 4,294 & 3.89 & 3.31 \\
\hline & New Delhi & 3,706 & 7.37 & 9.15 \\
\hline & Pimpri & 3,838 & 4.22 & 3.31 \\
\hline Sri Lanka & Sri Lanka & 3,345 & 10.40 & 7.41 \\
\hline Latin America & & & & \\
\hline Argentina & Neuquén & 1,930 & 11.35 & 16.48 \\
\hline & Rosario City & 2,952 & 6.30 & 9.79 \\
\hline Brazil & Aracaju & 2,443 & 13.10 & 8.64 \\
\hline & Itajaí & 1,511 & 11.05 & 9.79 \\
\hline & Maceió & 1,990 & 11.96 & 10.10 \\
\hline & Manaus Amazonas & 3,011 & 11.19 & 6.14 \\
\hline & Nova Iguaçu & 3,249 & 14.40 & 10.19 \\
\hline & Salvador & 1,069 & 11.51 & 26.47 \\
\hline & Santo Andre & 2,167 & 0.14 & 29.72 \\
\hline & São Paulo & 3,047 & 11.68 & 14.83 \\
\hline & São Paulo West & 3,312 & 16.06 & 13.35 \\
\hline Chile & Punta Arenas & 3,052 & 0.16 & 24.02 \\
\hline & South Santiago & 3,075 & 7.97 & 18.05 \\
\hline & Valdivia & 3,183 & 5.94 & 21.77 \\
\hline Colombia & Barranquilla & 3,209 & 17.23 & 13.24 \\
\hline & Bogotá & 3,256 & 15.14 & 14.28 \\
\hline & Cali & 3,005 & 20.30 & 14.08 \\
\hline Costa Rica & Costa Rica & 3,234 & 29.00 & 33.21 \\
\hline Cuba & La Habana & 1,803 & 13.59 & 20.91 \\
\hline Ecuador & Quito & 3,055 & 8.84 & 5.70 \\
\hline El Salvador & San Salvador & 1,365 & 27.69 & 10.40 \\
\hline Honduras & San Pedro Sula & 1,907 & 20.35 & 7.24 \\
\hline Mexico & Ciudad de México (1) & 3,205 & 33.35 & 9.64 \\
\hline & Ciudad de México (3) & 3,493 & 41.80 & 6.44 \\
\hline & Ciudad Victoria & 2,603 & 11.64 & 9.80 \\
\hline & Cuernavaca & 2,579 & 9.00 & 10.74 \\
\hline & Mérida & 2,896 & 16.23 & 19.68 \\
\hline & Mexicali Valley & 2,568 & 14.33 & 12.77 \\
\hline & Monterrey & 3,030 & 10.40 & 10.59 \\
\hline
\end{tabular}


eTable 2 (continued)

\begin{tabular}{|c|c|c|c|c|}
\hline Country & Center & No. of children & Intermittent rhinitis prevalence & Persistent rhinitis prevalence \\
\hline & Toluca & 3,235 & 10.39 & 7.54 \\
\hline & Villahermosa & 2,678 & 20.43 & 13.18 \\
\hline Nicaragua & Managua & 3,286 & 18.62 & 15.61 \\
\hline Panama & David-Panamá & 2,942 & 20.90 & 14.41 \\
\hline Uruguay & Paysandú & 1,512 & 6.75 & 11.11 \\
\hline Venezuela & Caracas & 2,999 & 8.64 & 21.94 \\
\hline \multicolumn{5}{|l|}{ North America } \\
\hline Barbados & Barbados & 2,759 & 5.15 & 4.49 \\
\hline Canada & Saskatoon & 1,255 & 3.43 & 21.35 \\
\hline \multicolumn{5}{|c|}{ Northern and Eastern Europe } \\
\hline Albania & Tiranë & 2,896 & 8.87 & 5.18 \\
\hline Bulgaria & Sofia & 1,181 & 6.01 & 5.50 \\
\hline Croatia & Rijeka & 1,633 & 3.74 & 12.80 \\
\hline Estonia & Tallinn & 2,385 & 4.99 & 7.59 \\
\hline Georgia & Kutaisi & 2,666 & 3.19 & 5.14 \\
\hline Hungary & Svábhegy & 2,451 & 1.75 & 10.53 \\
\hline \multirow[t]{2}{*}{ Kyrgyzstan } & Bishkek & 3,146 & 2.29 & 7.95 \\
\hline & Jalalabat & 1,664 & 14.72 & 7.39 \\
\hline \multirow[t]{3}{*}{ Lithuania } & Kaunas & 2,772 & 8.30 & 11.22 \\
\hline & Panevezys & 1,176 & 7.65 & 13.69 \\
\hline & Siauliai & 1,341 & 8.65 & 11.93 \\
\hline \multirow[t]{2}{*}{ Poland } & Krakow & 2,497 & 4.45 & 25.11 \\
\hline & Poznan & 1,999 & 3.75 & 22.41 \\
\hline Russia & Novosibirsk & 2,730 & 9.78 & 11.10 \\
\hline \multirow[t]{4}{*}{ Serbia and Montenegro } & Belgrade & 1,932 & 8.07 & 10.97 \\
\hline & $\mathrm{Nis}$ & 1,002 & 3.29 & 9.58 \\
\hline & Novi Sad & 1,044 & 6.51 & 6.99 \\
\hline & Sombor & 1,029 & 3.98 & 5.93 \\
\hline Sweden & Linköping & 2,089 & 1.58 & 10.29 \\
\hline \multirow[t]{2}{*}{ Ukraine } & Kharkiv & 1,950 & 2.31 & 6.21 \\
\hline & Rural Kharkiv & 3,000 & 15.57 & 4.87 \\
\hline \multicolumn{5}{|l|}{ Oceania } \\
\hline Australia & Melbourne & 2,968 & 5.63 & 18.09 \\
\hline \multirow[t]{4}{*}{ New Zealand } & Auckland & 3,541 & 6.07 & 16.77 \\
\hline & Bay of Plenty & 2,150 & 4.65 & 18.00 \\
\hline & Christchurch & 3,315 & 3.59 & 19.16 \\
\hline & Nelson & 1,867 & 3.00 & 15.05 \\
\hline Niue & Niue Island & 47 & 12.77 & 6.38 \\
\hline \multicolumn{5}{|l|}{ Western Europe } \\
\hline \multirow[t]{2}{*}{ Austria } & Kärnten & 4,847 & 2.58 & 7.49 \\
\hline & Urfahr-Umgebung & 2,029 & 2.61 & 9.46 \\
\hline Belgium & Antwerp & 5,645 & 3.21 & 12.31 \\
\hline Germany & Münster & 3,830 & 2.61 & 12.72 \\
\hline Greece & Thessaloniki & 1,228 & 10.26 & 4.97 \\
\hline Isle of Man & Isle of Man & 1,096 & 2.65 & 13.14 \\
\hline \multirow[t]{10}{*}{ Italy } & Bari & 1,943 & 7.05 & 12.09 \\
\hline & Colleferro-Tivoli & 1,143 & 2.97 & 12.51 \\
\hline & Emilia-Romagna & 2,265 & 4.06 & 12.54 \\
\hline & Empoli & 1,152 & 4.17 & 12.15 \\
\hline & Firenze & 1,036 & 4.15 & 13.32 \\
\hline & Mantova & 1,288 & 3.65 & 12.27 \\
\hline & Milano & 2,249 & 4.36 & 13.34 \\
\hline & Roma & 2,224 & 4.27 & 14.61 \\
\hline & Torino & 2,361 & 4.62 & 12.88 \\
\hline & Trento & 2,359 & 2.67 & 9.71 \\
\hline Portugal & Funchal & 1,819 & 8.80 & 11.16 \\
\hline & Lisbon & 2,477 & 8.48 & 15.46 \\
\hline & Portimao & 1,069 & 0 & 21.33 \\
\hline & Porto & 2,464 & 8.16 & 11.73 \\
\hline Spain & A Coruña & 3,016 & 6.60 & 13.66 \\
\hline & Almeria & 3,349 & 5.32 & 11.38 \\
\hline & Asturias & 3,193 & 7.23 & 12.18 \\
\hline & Barcelona & 3,002 & 2.73 & 5.26 \\
\hline & Bilbao & 3,157 & 5.99 & 10.96 \\
\hline & Cartagena & 2,948 & 5.90 & 9.77 \\
\hline & Castellón & 3,915 & 3.32 & 10.19 \\
\hline & Madrid & 2,347 & 10.01 & 11.55 \\
\hline & Pamplona & 3,176 & 3.21 & 6.77 \\
\hline & Valencia & 3,398 & 6.00 & 7.56 \\
\hline
\end{tabular}


eTable 3

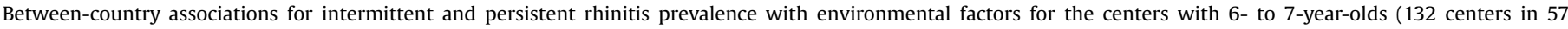
countries) $)^{\mathrm{a}}$

\begin{tabular}{|c|c|c|}
\hline \multirow[t]{2}{*}{ Country-level environmental factor } & \multicolumn{2}{|c|}{ Average difference in country-level prevalence $(95 \% \mathrm{CI})$ per 100 children per 1 - $\mathrm{U}$ increase in country-level exposure } \\
\hline & Intermittent rhinitis & Persistent rhinitis \\
\hline \multicolumn{3}{|l|}{ Temperature } \\
\hline Mean $\left(10.6^{\circ} \mathrm{C}\right)$ & $0.28(-0.07$ to 0.64$)$ & $0.09(-0.30$ to 0.47$)$ \\
\hline $\operatorname{Maximum}\left(5.3^{\circ} \mathrm{C}\right)$ & $0.06(-0.33$ to 0.46$)$ & $-0.17(-0.65$ to 0.31$)$ \\
\hline Minimum $\left(16.8^{\circ} \mathrm{C}\right)$ & $0.22(-0.03$ to 0.47$)$ & $0.11(-0.16$ to 0.39$)$ \\
\hline $\mathrm{SD}\left(2.1^{\circ} \mathrm{C}\right)$ & $-0.24(-1.04$ to 0.57$)$ & $-0.52(-1.46$ to 0.42$)$ \\
\hline Maximal difference $\left(13.4^{\circ} \mathrm{C}\right)$ & $-0.32(-0.56 \text { to }-0.07)^{\mathrm{b}}$ & $-0.09(-0.37$ to 0.18$)$ \\
\hline \multicolumn{3}{|l|}{ Precipitation } \\
\hline Mean $(67.7 \mathrm{~mm})$ & 0.03 (0 to 0.07$)$ & $0.02(-0.02$ to 0.06$)$ \\
\hline Maximum (201.2 mm) & $0.02(0 \text { to } 0.04)^{b}$ & $0.01(-0.01$ to 0.03$)$ \\
\hline Minimum (28.6 mm) & $-0.04(-0.10$ to 0.02$)$ & $-0.01(-0.08$ to 0.07$)$ \\
\hline $\mathrm{SD}(64.6 \mathrm{~mm})$ & $0.09(0.04 \text { to } 0.14)^{c}$ & $0.04(-0.02$ to 0.10$)$ \\
\hline Maximal difference (182.99 mm) & $0.03(0.01 \text { to } 0.05)^{c}$ & $0.02(-0.01$ to 0.04$)$ \\
\hline \multicolumn{3}{|l|}{ Vapor pressure } \\
\hline Mean $(11.1 \mathrm{hPa})$ & $0.25(-0.07$ to 0.57$)$ & $0.18(-0.19$ to 0.54$)$ \\
\hline Maximum (9.8 hPa) & $0.12(-0.16$ to 0.40$)$ & $0.04(-0.30$ to 0.38$)$ \\
\hline Minimum (10.6 hPa) & $0.31(0$ to 0.62$)$ & $0.19(-0.16$ to 0.55$)$ \\
\hline $\mathrm{SD}(1.9 \mathrm{hPa})$ & $0.02(-1.05$ to 1.09$)$ & $-0.37(-1.68$ to 0.94$)$ \\
\hline Maximal difference (5.4 hPa) & $-0.30(-0.61$ to 0.01$)$ & $-0.11(-0.50$ to 0.28$)$ \\
\hline \multicolumn{3}{|l|}{ Vegetation $^{\mathrm{d}}$} \\
\hline Mean (0.1) & $3.90(-10.82$ to 18.62$)$ & $14.23(-2.35$ to 30.81$)$ \\
\hline Maximum (0.2) & $4.84(-8.09$ to 17.78$)$ & $10.06(-4.81$ to 24.94$)$ \\
\hline Minimum (0.1) & $0.81(-14.67$ to 16.29$)$ & $13.98(-3.39$ to 31.35$)$ \\
\hline $\mathrm{SD}(0.03)$ & $3.62(-39.50$ to 46.74$)$ & $11.00(-37.10$ to 59.10$)$ \\
\hline Maximal difference $(0.1)$ & $4.90(-9.54$ to 19.33$)$ & $1.06(-15.70$ to 17.82$)$ \\
\hline
\end{tabular}

Abbreviation: $\mathrm{CI}$, confidence interval.

${ }^{a}$ All models adjusted for center mean exposure of interest, center and country mean population density, country gross national income per capita, and climate type. ${ }^{\mathrm{b}} \mathrm{P}<.05$.

${ }^{\mathrm{c}} \mathrm{P}<.01$.

${ }^{\mathrm{d}}$ Vegetation data only available for 131 centers in 56 countries.

\section{eTable 4}

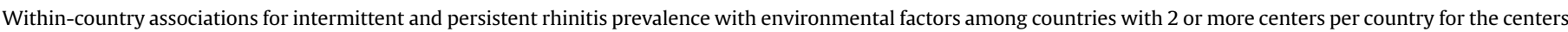
With 6- to 7-year-olds (98 centers in 23 countries) ${ }^{a}$

\begin{tabular}{|c|c|c|}
\hline \multirow[t]{2}{*}{ Center-level environmental factor } & \multicolumn{2}{|c|}{ Mean difference in center-level prevalence $(95 \% \mathrm{CI})$ per 100 children per 1 - $U$ increase in center-level exposure } \\
\hline & Intermittent rhinitis & Persistent rhinitis \\
\hline \multicolumn{3}{|l|}{ Temperature } \\
\hline Mean $\left(10.9^{\circ} \mathrm{C}\right)$ & $-0.37(-0.85$ to 0.10$)$ & $0.42(-0.01$ to 0.84$)$ \\
\hline Maximum $\left(7.2^{\circ} \mathrm{C}\right)$ & $-0.33(-0.72$ to 0.07$)$ & $0.32(-0.02$ to 0.67$)$ \\
\hline Minimum $\left(13.4^{\circ} \mathrm{C}\right)$ & $-0.32(-0.77$ to 0.13$)$ & $0.32(-0.09$ to 0.74$)$ \\
\hline $\mathrm{SD}\left(2.4^{\circ} \mathrm{C}\right)$ & $-0.16(-1.56$ to 1.24$)$ & $0.48(-0.77$ to 1.72$)$ \\
\hline Maximal difference $\left(12.7^{\circ} \mathrm{C}\right)$ & $-0.02(-0.48$ to 0.43$)$ & $0.13(-0.28$ to 0.55$)$ \\
\hline \multicolumn{3}{|l|}{ Precipitation } \\
\hline Mean $(57.2 \mathrm{~mm})$ & $0.01(-0.04$ to 0.05$)$ & $0.01(-0.03$ to 0.05$)$ \\
\hline Maximum (177.7 mm) & $0(-0.02$ to 0.02$)$ & $0(-0.02$ to 0.01$)$ \\
\hline Minimum (30.2 mm) & $-0.01(-0.08$ to 0.06$)$ & $0(-0.06$ to 0.06$)$ \\
\hline $\mathrm{SD}(68.5 \mathrm{~mm})$ & $0(-0.04$ to 0.05$)$ & $-0.01(-0.05$ to 0.03$)$ \\
\hline Maximal difference (172.05 mm) & $0(-0.02$ to 0.02$)$ & $0(-0.02$ to 0.01$)$ \\
\hline \multicolumn{3}{|l|}{ Vapor pressure } \\
\hline Mean $(9.0 \mathrm{hPa})$ & $-0.38(-0.79$ to 0.03$)$ & $0.42(0.05 \text { to } 0.79)^{\mathrm{b}}$ \\
\hline Maximum (11.4 hPa) & $-0.30(-0.62$ to 0.03$)$ & $0.32(0.03 \text { to } 0.61)^{b}$ \\
\hline Minimum (7.9 hPa) & $-0.25(-0.71$ to 0.20$)$ & $0.45(0.04 \text { to } 0.86)^{b}$ \\
\hline $\mathrm{SD}(2.2 \mathrm{hPa})$ & $-0.09(-1.38$ to 1.20$)$ & $0.63(-0.50$ to 1.77$)$ \\
\hline Maximal difference (5.7 hPa) & $-0.17(-0.66$ to 0.31$)$ & $0.25(-0.19$ to 0.69$)$ \\
\hline \multicolumn{3}{|l|}{ Vegetation } \\
\hline Mean (0.1) & $-9.05(-19.66$ to 1.55$)$ & $8.37(-1.04$ to 17.77$)$ \\
\hline Maximum (0.2) & $-7.58(-17.01$ to 1.85$)$ & $8.81(0.53 \text { to } 17.09)^{\mathrm{b}}$ \\
\hline Minimum (0.1) & $-8.11(-19.77$ to 3.55$)$ & $6.90(-3.52$ to 17.31$)$ \\
\hline $\mathrm{SD}(0.05)$ & $-30.47(-74.18$ to 13.25$)$ & $33.08(-5.55$ to 71.71$)$ \\
\hline Maximal difference $(0.2)$ & $-5.49(-20.63$ to 9.66$)$ & $11.09(-2.22$ to 24.40$)$ \\
\hline
\end{tabular}

Abbreviation: $\mathrm{CI}$, confidence interval.

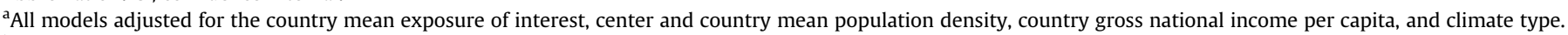
${ }^{\mathrm{b}} \mathrm{P}<.05$. 
eTable 5

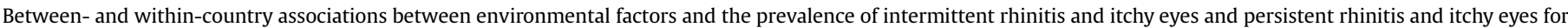
the centers with 13- to 14-year-olds ${ }^{a}$

\begin{tabular}{|c|c|c|c|c|}
\hline \multirow[t]{2}{*}{ Environmental factor } & \multicolumn{2}{|c|}{$\begin{array}{l}\text { Mean difference in country-level prevalence }(95 \% \mathrm{CI}) \text { per } 100 \\
\text { children per } 1-\mathrm{U} \text { increase in country-level exposure }\end{array}$} & \multicolumn{2}{|c|}{$\begin{array}{l}\text { Mean difference in center-level prevalence }(95 \% \mathrm{CI}) \text { per } 100 \\
\text { children per } 1-\mathrm{U} \text { increase in center-level exposure }^{\mathrm{C}}\end{array}$} \\
\hline & Intermittent rhinitis and itchy eyes & Persistent rhinitis and itchy eyes & Intermittent rhinitis and itchy eyes & Persistent rhinitis and itchy eyes \\
\hline \multicolumn{5}{|l|}{ Temperature } \\
\hline Mean & $0.36(0.16 \text { to } 0.56)^{d}$ & $0.03(-0.14$ to 0.21$)$ & $0.23(0.05 \text { to } 0.42)^{e}$ & $0.13(-0.07$ to 0.32$)$ \\
\hline Maximum & $0.17(-0.09$ to 0.43$)$ & $-0.07(-0.27$ to 0.14$)$ & $0.21(0.04 \text { to } 0.38)^{\mathrm{e}}$ & $0.15(-0.02$ to 0.32$)$ \\
\hline Minimum & $0.27(0.13 \text { to } 0.41)^{d}$ & $0.03(-0.10$ to 0.16$)$ & $0.14(-0.03$ to 0.30$)$ & $0(-0.18$ to 0.17$)$ \\
\hline SD & $-0.60(-1.15 \text { to }-0.06)^{e}$ & $-0.21(-0.67$ to 0.25$)$ & $0.49(-0.02$ to 1.01$)$ & $0.61(0.08 \text { to } 1.13)^{e}$ \\
\hline Maximal difference & $-0.25(-0.40 \text { to }-0.09)^{\mathrm{d}}$ & $-0.04(-0.18$ to 0.10$)$ & $0.10(-0.08$ to 0.28$)$ & 0.18 (0 to 0.37$)$ \\
\hline \multicolumn{5}{|l|}{ Precipitation } \\
\hline Mean & $0.02(0 \text { to } 0.04)^{\mathrm{e}}$ & $0(-0.01$ to 0.02$)$ & $-0.02(-0.04 \text { to } 0)^{\mathrm{e}}$ & $-0.01(-0.03$ to 0.01$)$ \\
\hline Maximum & $0.01(0 \text { to } 0.02)^{e}$ & $0(-0.01$ to 0.01$)$ & $0(-0.01$ to 0$)$ & $-0.01(-0.02$ to 0$)$ \\
\hline Minimum & $0(-0.03$ to 0.04$)$ & $0.01(-0.02$ to 0.04$)$ & $-0.03(-0.06 \text { to } 0)^{\mathrm{e}}$ & $-0.01(-0.03$ to 0.02$)$ \\
\hline SD & $0.04(0.01 \text { to } 0.07)^{\mathrm{d}}$ & $0(-0.03$ to 0.03$)$ & $-0.01(-0.03$ to 0.02$)$ & $-0.02(-0.04$ to 0$)$ \\
\hline Maximal difference & $0.02(0$ to 0.03$)$ & $0(-0.01$ to 0.01$)$ & $0(-0.01$ to 0.01$)$ & $-0.01(-0.02$ to 0$)$ \\
\hline \multicolumn{5}{|l|}{ Vapor pressure } \\
\hline Mean & $0.33(0.14 \text { to } 0.53)^{\mathrm{d}}$ & $0.11(-0.07$ to 0.28$)$ & $0.11(-0.06$ to 0.28$)$ & $0.10(-0.07$ to 0.28$)$ \\
\hline Maximum & $0.24(0.04 \text { to } 0.43)^{e}$ & $0.09(-0.07$ to 0.25$)$ & $0.11(-0.02$ to 0.24$)$ & $0.10(-0.03$ to 0.24$)$ \\
\hline Minimum & $0.32(0.13 \text { to } 0.51)^{d}$ & $0.10(-0.07$ to 0.28$)$ & $0.15(-0.04$ to 0.35$)$ & $0.13(-0.06$ to 0.33$)$ \\
\hline $\mathrm{SD}$ & $0(-0.80$ to 0.80$)$ & $0.25(-0.39$ to 0.88$)$ & $0.62(0.13 \text { to } 1.11)^{\mathrm{e}}$ & $0.60(0.09 \text { to } 1.10)^{e}$ \\
\hline Maximal difference & $-0.19(-0.44$ to 0.05$)$ & $0.03(-0.17$ to 0.23$)$ & $0.14(-0.05$ to 0.32$)$ & $0.11(-0.08$ to 0.30$)$ \\
\hline \multicolumn{5}{|l|}{ Vegetation } \\
\hline Mean & $6.22(-2.66 \text { to } 15.10)^{f}$ & $6.00(-1.36 \text { to } 13.36)^{f}$ & $-0.74(-5.17$ to 3.70$)$ & $-2.56(-7.03$ to 1.91$)$ \\
\hline Maximum & $3.18(-4.70 \text { to } 11.05)^{f}$ & $4.22(-2.37 \text { to } 10.81)^{f}$ & $-0.28(-4.18$ to 3.62$)$ & $-0.73(-4.69$ to 3.24$)$ \\
\hline Minimum & $6.83(-2.65 \text { to } 16.32)^{f}$ & $6.39(-1.39 \text { to } 14.18)^{\mathrm{f}}$ & $-1.39(-6.33$ to 3.56$)$ & $-4.33(-9.30$ to 0.63$)$ \\
\hline SD & $-3.19(-31.33 \text { to } 24.95)^{f}$ & $6.49(-17.42 \text { to } 30.40)^{\mathrm{f}}$ & $0.49(-16.75$ to 17.73$)$ & $3.59(-14.00$ to 21.18$)$ \\
\hline Maximal difference & $-2.28(-12.17 \text { to } 7.60)^{f}$ & $-0.19(-8.52 \text { to } 8.14)^{\mathrm{f}}$ & $1.26(-4.57$ to 7.09$)$ & $4.31(-1.59$ to 10.22$)$ \\
\hline
\end{tabular}

Abbreviation: $\mathrm{CI}$, confidence interval.

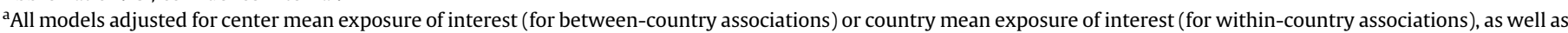
the center and country mean population density, country gross national income per capita, and climate type.

${ }^{\mathrm{b}}$ On the basis of data from 222 centers in 94 countries.

${ }^{\mathrm{c}} \mathrm{On}$ the basis of data from 165 centers in 37 countries.

${ }^{\mathrm{d}} \mathrm{P}<.01$.

${ }^{\mathrm{e}} \mathrm{P}<.05$.

fVegetation data only available for 215 centers in 87 countries. 